UPPSALA UNIVERSITET
Working Paper 2006:26

Department of Economics

How Successful is the Dual Income Tax?

Evidence from the Finnish Tax Reform of 1993

Jukka Pirttilä and Håkan Selin 
Department of Economics

Uppsala University

P.O. Box 513

SE-751 20 Uppsala

Sweden

Fax: +46184711478
Working paper 2006:26

November 2006

ISSN 1653-6975

How Successful is the Dual Income Tax?

EvidenCE FROM THE FinNish TAx REFoRm of 1999

Jukka Pirttilä and HÅkan Selin

Papers in the Working Paper Series are published on internet in PDF formats.

Download from http://www.nek.uu.se

or from S-WoPEC http://swopec.hhs.se/uunewp/ 


\title{
How Successful is the Dual Income Tax? \\ Evidence from the Finnish Tax Reform of 1993*
}

Jukka Pirttilä ${ }^{\mathrm{a}}$ and Håkan Selin ${ }^{\mathrm{b}}$

November, 2006

\begin{abstract}
Dual income tax systems have become increasingly popular; yet, relatively little is known about the consequences of implementing such tax systems. This paper uses a representative panel of taxpayers from the 1993 Finnish tax reform to measure how overall taxable income and the relative shares of capital income and labour income reacted to the reform. The Finnish tax reform appears to be particularly suitable for analysing the effect of separating labour and capital income tax bases. The reform radically reduced the marginal tax rates on capital income to some, but not all, taxpayers, while the taxation of labour income was not reformed at the same time. We find that the reform led to a small positive impact on overall taxable income, but part of the positive response was probably offset by income shifting among the self-employed.
\end{abstract}

Key words: Taxable income, income shifting, dual tax system

JEL classification: C21, H21, H31

\footnotetext{
* We are grateful to Sören Blomquist, Ilpo Suoniemi, Jan Södersten, Thor O. Thoresen and seminar participants at the Labour Institute for Economic Research, Government Institute for Economic Research (VATT), Uppsala University, and the IIPF Congress 2006 for helpful comments. Special thanks are due to Pertti Honkanen for providing us with the data on marginal tax rates from the JUTTA microsimulation model. Financial support from the Employee Foundation, the Yrjö Jahnsson Foundation and the Jan Wallander and Tom Hedelius Foundation is gratefully acknowledged.

${ }^{a}$ Labour Institute for Economic Research, Pitkänsillanranta 3 A, 00530 Helsinki, Finland, E-mail:

<jukka.pirttila@labour.fi>

${ }^{\mathrm{b}}$ Department of Economics, Uppsala University, P.O. Box 513, SE-751 20 Uppsala, Sweden, E-mail:

$<$ hakan.selin@nek.uu.se>
} 


\section{Introduction}

Dual income tax systems - with a progressive tax on earned income and a proportional tax on capital income - were first implemented in four Nordic countries (Denmark, Finland, Norway and Sweden) through a number of tax reforms from 1987 to $1993 .{ }^{1}$ But this tax system appears to be increasingly popular otherwise as well. In Germany, the Council of Economic Experts suggested in 2003 that Germany ought to move towards a dual income tax. And in the US in 2005, the President's Advisory Panel on Federal Tax Reform proposed two alternative plans to simplify the US federal tax code. One of these proposals, the Growth and Investment Tax Plan, is essentially a type of dual income tax, with an individual level, flat 15\%, surcharge on dividends, interests and capital gains.

As recent overviews by Boadway (2004) and Sørensen (2005b) make clear, the dual income tax system has, no doubt, several merits. It allows for a more favourable tax treatment of capital income, something which is very likely desirable from the efficiency point of view. The system also treats different sorts of capital income in a neutral way, thus avoiding the myriads of tax concessions for some types of capital income typically involved in comprehensive income tax systems. And it also serves as a way in which to react to capital income tax competition.

In the Nordic countries that have more than ten years of experience with the system, an increasing concern has, however, emerged about what is often called the Achilles' heel of the dual income tax, i.e. the incentives the system creates for tax avoidance through income shifting (see, for instance, the discussion by Sandmo 2005). Owing to a large gap between the marginal tax rate on labour income and capital income, high-income earning individuals may try to shift part of their labour income tax base into the capital income tax base. This possibility tends to increase the efficiency costs of the tax system, and it may also erode the intended progressivity of taxation.

The purpose of this paper is to assess some aspects of the success of a dual income tax system using a representative panel of taxpayers before and after the Finnish dual income tax reform in 1993 (henceforth, DTR93). The focus will be on two specific outcomes of the reform. First, by examining the response of taxable capital income and taxable total income, we evaluate the magnitude of potential efficiency gains related to the reform. And second, we attempt to estimate to what extent

\footnotetext{
${ }^{1}$ For an introduction to the dual tax system, see Sørensen (1998).
} 
some of these gains were offset by income-shifting activities. The Finnish tax reform is particularly suitable for examining the impacts of a dual tax reform, since the gap between the marginal tax rates on labour vs. capital income was also the greatest in the Finnish case (Sørensen 1998, Table 1). After the reform, all capital income was taxed at a flat 25\% rate, whereas the highest marginal tax rate on earned income was approximately 63\%, leaving a gap of 38 percentage points in the two marginal tax rates for the high-income earners. In addition, unlike in other Nordic countries, the labour income part of the tax system was not reformed at the same time. ${ }^{2}$ Despite this, some people saw an important variation in the marginal tax rate on labour income as the tax base for the progressively taxed income was reduced to labour income only.

One of the consequences of the reform was, indeed, a strong increase in the share of capital income out of all taxable income. This can be seen from Figure 1, which documents the share of capital income out of all income before the reform (1992), some time after the reform (1995) and for the most recent year available for the study (2002) on average, for the $10^{\text {th }}$ decile and for the top $1 \%$ of income earners. The rise in the share of capital income has been most dramatic for the top $1 \%$, for whom the importance of capital income is now larger than that of earned income.

The way in which we assess the reform in this paper builds on empirical analysis of how changes in marginal tax rates affected overall (taxable) income and, in particular, the composition of income (earned income vs. capital income). Our approach is closely related to the literature on the elasticity of taxable income, along the lines of Feldstein (1995) and a large amount of subsequent research ${ }^{3}$, where overall taxable income is regressed on the net-of-tax rate (one minus the marginal tax rate). However, in contrast to earlier studies in this literature, we will have to consider two separate income tax bases and net-of-tax rates. We use panel data of individuals from the 1992 Finnish Income Distribution Survey and their tax register data from 1995. This three-year time span is typically used in the elasticity of the taxable income literature. The basic identification strategy is to make use of the large variation in marginal tax changes between individuals and test to see whether this can explain individual differences in labour and capital income between these years, controlling for other aspects found important in the earlier literature.

\footnotetext{
${ }^{2}$ In Finland, income tax progressivity was reduced during the years preceding DTR93.

${ }^{3}$ This research has been summarised by e.g. Saez (2004). More recent work on US data includes Kopczuk (2005) and Giertz (2006). See also Slemrod (1998) for a useful guide on interpreting taxable income elasticities.
} 
While marginal capital tax rates can also influence labour supply, one suspects that the key real behavioural change is related to savings behaviour. But especially in the short run, the taxpayer can also react through income shifting between the two differently treated tax bases. Therefore, even though our study is restricted to the personal income tax base, our paper is also related to the literature on income shifting between the personal and corporate tax base, where key references include Gordon and MacKie-Mason (1994) and Gordon and Slemrod (2000). The possibility of income shifting is taken into account in Carroll and Hrung (2005), who calculate that income shifting may offset 22-37 per cent of overall increase in the taxable income owing to tax changes.

Previous studies on Nordic dual income tax reforms (see e.g. Sørensen (1998), Lindhe et al. (2002, 2004)) have also discussed the incentives for the owners of small businesses to transform labour income into capital income. In the Finnish case, chief among the income-shifting possibilities was the possibility for owners of closely held corporations to increase the share taxed as capital income by expanding the net worth of the corporation. Likewise, the self-employed could increase capital income by expanding the net worth, even though it could be even more efficient to incorporate. ${ }^{4}$ In the absence of firm-level data we cannot directly observe income shifting in the empirical application. We have, however, some means to differentiate between 'real' behavioural change (savings behaviour) and income shifting by comparing the outcomes for persons with plausible differences in the costs associated with income shifting (entrepreneurs vs. employees). ${ }^{5}$

Our paper is also related to a number of earlier taxable income studies on the Scandinavian tax systems. Aarbu and Thoresen (2001) examine the tax reform in Norway, whereas Hansson (2004), Ljunge and Ragan (2004) and Selén (2005) focus on the Swedish tax system. None of them, however, focuses on the composition of labour and capital income and income shifting between the bases. ${ }^{6}$ In addition, Fjaerli (2004) utilises the change towards the dual tax system when measuring the impacts of tax incentives on household debt, based on panel data from Norway. Using Norwegian firm-level data, Fjaerli and Lund (2001) have undertaken a study showing that the choice between the owner's wages and dividends under the Norwegian dual income tax is driven by both tax and non-tax factors, such as rights to social benefits. Finally, a couple of studies focus on the effects of the Finnish DTR93, but from a completely different point of view. In a theoretical analysis,

\footnotetext{
${ }^{4}$ There was, indeed, an increase in the number of incorporations following the reform in 1993 (Riihelä et al 2005).

${ }^{5} \mathrm{Wu}(2005)$ reports that the tax elasticity of privately held corporations in the US appears to be high. He does not, however, consider the extent of income shifting between corporate and personal tax bases.

${ }^{6}$ Even though Aarbu and Thoresen (2001) control for the difference between the labour and capital tax rate in their regressions. Hansson (2004) adheres to this method.
} 
Kari (1999) examines the cost of capital of closely held corporations after the reform, while Valkonen (1999) evaluates the overall impacts of the reform on the economy using a computable general equilibrium approach.

The paper is organised as follows. Section 2 briefly describes the Finnish tax reform in 1993. Section 3 builds a small theoretical framework, to help concentrate thoughts on the key behavioural mechanisms, and discusses our empirical approach. Section 4 presents the data and explains issues related to the construction of tax bases and different measures of marginal tax rates. The estimation results from the main specifications are presented in Section 5, while Section 6 analyses the robustness of the results. Section 7 concludes.

\section{The Finnish Tax Reform of 1993}

Until the end of 1992, Finland had a global income tax, where all income was treated, in principle, in the same way. ${ }^{7}$ Table 1 depicts the progressive state income tax schedule which was effective in 1992. Taking into account proportional local tax rates and relevant statutory surcharges, the highest marginal income tax rate was $62 \%$ in 1992 and $63 \%$ in $1995 .^{8}$

Although much of the income was taxed non-linearly in 1992, there were considerable differences across income sources, as tax deductions differed. Two key deductions, which were also subject to a change in the tax reform of 1993, were a deduction for interest expenses and an allowance on the basis of capital income. Interest expenses were deductible to roughly $75 \%$ of the interest payments of loans for owner-occupied housing up to 20,000 FIM. Based on the allowance on the basis of capital income, taxpayers could also deduct roughly 50\% of many types of capital income, again up to 20,000 FIM. This meant that up to a certain level, capital income was subject to a lower - but still progressive - marginal tax rate than labour income. The effective tax rate also differed for dif-

\footnotetext{
${ }^{7}$ Very wealthy individuals had to pay property tax as well, at a rate of $0.9 \%$ of taxable property exceeding $1,100,000$ FIM.

${ }^{8}$ The average local income tax rate was $16.8 \%$ in 1992, $17.2 \%$ in 1993 and 17.5\% in 1995. In 1992, taxpayers also had to pay $3.05 \%$ of their taxable income as a social insurance contribution and $1.7 \%$ as a health insurance contribution. For income exceeding 80,000 FIM, there was a health insurance contribution surcharge equal to 1.5\% of taxable income. After the tax reform, the rate for the social insurance contribution was $1.8 \%$ of taxable earned income. The health insurance contribution was $1.9 \%$ and the health insurance surcharge was kept unchanged. In addition, new pension insurance and unemployment insurance contributions were launched, with rates of $3 \%$ and $0.2 \%$ from gross wage income, respectively. These payments were, however, tax deductible. In both years, there was also a basic allowance for individuals with a very low income level.
} 
ferent types of capital income. A large amount of interest income was taxed at a rate of $15 \%$ in 1992.

With respect to personal taxation, the two key ingredients of the 1993 reform were as follows:

- The progressive state income tax schedule, depicted in Table 1, was now only relevant for earned income (labour income, social security benefits etc.). As capital income was removed from the labour income tax base, those with positive capital income ceteris paribus faced lower labour marginal tax rates after the reform. Conversely, those with negative capital income saw higher marginal tax rates for labour income. In principle, all forms of capital income (dividends, rents, interest income, capital gains, etc.) were subject to a flat tax of $25 \%{ }^{9}$

- The deduction of interest expenses was replaced by a two-part system. Interest payments became deductible against capital income. When the taxpayer had insufficient capital income to claim deductions on these, a credit for a deficit in capital income emerged. This was a deduction granted from the tax on earned income on the basis of expenses incurred in acquiring income, interest expenses or certain forms of financial losses. This move also considerably reduced the tax-favoured position of loans related to owner-occupied housing. Only $25 \%$ of interest payments on these loans, up to a limit of 8,000 FIM for singles, ${ }^{10}$ could be deducted from the tax on labour income. Furthermore, the allowance on the basis of capital income was abolished.

These moves altogether meant that there was a significant gap between the marginal tax rate on labour and capital income for many of the taxpayers - for taxpayers with the highest marginal tax rate, the difference was almost 38 percentage points. For individuals with a high marginal tax rate in 1992, the marginal tax rate on capital income dropped significantly, whereas the change was much smaller for individuals with low income. However, the drop was mitigated by the abolishment of allowance on the basis of capital income.

The 1993 reform implied substantial changes for all main organisational forms for small firms, i.e. closely held corporations, partnerships and sole proprietorships. ${ }^{11}$ In order to prevent income shift-

\footnotetext{
${ }^{9}$ Although during a transitory period, the withholding tax on interest income was lower, $20 \%$.

${ }^{10}$ 10,000 FIM for singles with one child under 18 years of age and 12,000 FIM for many children. The limits for spouses were 16,000 without children, 18,000 for one child and 20,000 for many children.

${ }^{11}$ One consequence of the reform was that neither general nor limited partnerships were treated as separable taxable entities anymore in 1993. Analogous to sole proprietorships all income from partnerships became taxed at the personal level. Before the reform, a so-called halving method was used for generalised and limited partnerships. This system implied that half of the business income was taxed at the corporate level and half at the level of the partners. In con-
} 
ing, business and dividend income were split into one labour income and one capital income component. For owners of partnership and sole proprietors business income was split such that an amount corresponding to a certain fraction, 15 per cent, of the net worth of the enterprise was taxed as capital income and the residual as labour income. Owners of closely held corporations had the option to extract profits either as wage income or as dividend income. Dividends not listed on the stock exchange were split in a similar manner as business income, based on the net worth of the company. $^{12}$

On the corporate side, an imputation credit system, which aimed at eliminating double taxation of dividends, was introduced as early as 1990. This system implied that an amount corresponding to the tax paid by the corporation in profit tax was deducted from the tax of the shareholder. The imputation system was retained in the 1993 reform, where the nominal corporate profit tax rate was also reduced to $25 \%$, i.e. equal to the capital income tax rate. The cut in the nominal tax rate was accompanied by base broadening measures. ${ }^{13}$

\section{Theoretical Framework and Empirical Approach}

\section{A. A Simple Model}

The following simple model is intended to shed light on our empirical approach. Suppose that a representative individual maximises the well behaved utility function $U=U(C, X, L)$, where $C$ is present consumption, $X$ future consumption and $L$ leisure. We assume that the individual is located on linear segments both on the labour and capital income tax functions. In the absence of income shifting, the budget constraint can be written as

$$
C+\frac{1}{1+\left(1-t_{c}\right) r} X=\left(1-t_{l}\right) w(\bar{L}-L)+R
$$

where $t_{l}$ is the labour marginal tax rate, $t_{c}$ the capital marginal tax rate, $r$, the interest rate, $\bar{L}$ the time constraint, $w$ the hourly wage rate and $R$ is virtual income. Literally, this model is, of course, a two-period model with zero hours of work in the second period. Now, suppose that the individual

\footnotetext{
trast, closely held corporations, which in Finland should be defined as companies not listed on the stock exchange, were, of course, taxed as separable entities according to the $25 \%$ corporate profit tax rate.

${ }^{12}$ See Appendix for a more detailed description of the income-shifting technologies.

${ }^{13}$ Most importantly, deductions through operating reserves and undervaluation of inventory were abolished in corporate taxation. The possibility to use operating reserves was, however, retained for sole proprietorships and partnerships. Also, maximum depreciation rates and a number of other deduction possibilities were reduced.
} 
has the opportunity to shift his or her income between the labour and capital income tax base. If there were no costs associated with income shifting, the utility maximising agent would shift all their income to the more leniently taxed base. In reality, we could not expect this to be the case. Let $\kappa \in(0,1]$ be a summarising parameter for the exogenous factors determining the cost of income shifting. These could be thought of as individual characteristics such as self-employment status. We introduce a cost function to the budget constraint, $\Gamma(\eta ; \kappa)$, where $\eta$ is the amount of income shifted. ${ }^{14} \Gamma(\eta ; \kappa)$ is assumed to be decreasing in $\kappa$. Suppose, for simplicity, that the cost function takes the following form, $\Gamma=\frac{\Psi(\eta)}{\kappa}$. The budget constraint can now be written

$$
C+\frac{1}{1+r} X+m(K+\eta)=w(\bar{L}-L)-t_{l}[w(\bar{L}-L)-\eta]-\frac{\Psi(\eta)}{\kappa}+R
$$

where $m=\frac{t_{c}}{1+\left(1-t_{c}\right) r}$ can be interpreted as the present value of the marginal capital tax rate and $K=\frac{r X}{(1+r)}$ as the present value of interest income. The consumer maximises utility with respect to $C, X, L$ and $\eta$. Denoting the Lagrange multiplier by $\lambda$, the first-order condition for $\eta$ can be written as

$$
-\lambda\left(m-t_{l}+\frac{\psi_{\eta}}{\kappa}\right)=0
$$

From (2) we infer that $\psi_{\eta}=\kappa\left(t_{l}-m\right)$, i.e. after maximisation, the marginal cost of income shifting is equal to the marginal benefit of income shifting, which in turn is equal to the difference between the marginal labour and capital tax rates times the degree of entrepreneurial status. In a linearised version of the model, the marginal cost can be expressed as $\theta=\kappa\left(t_{l}-m\right)$, directly entering the optimisation problem of the individual. Henceforth, we will denote labour income by $L I$ and capital income by $C I$. Expressing hours worked as $H=\bar{L}-L$, we can write the optimal taxable income functions as aggregates of the supply and reaction functions:

\footnotetext{
${ }^{14}$ See Slemrod $(1994,2001)$ for theoretical studies where avoidance opportunities represented by a cost function are present.
} 


$$
\begin{aligned}
& L I^{*}=H^{*}\left[t_{l}, t_{c}, \kappa, \kappa\left(t_{l}-m\right), r, w, R\right]-\eta^{*}\left[t_{l}, t_{c}, \kappa, \kappa\left(t_{l}-m\right), r, w, R\right] \\
& C I^{*}=K^{*}\left[t_{l}, t_{c}, \kappa, \kappa\left(t_{l}-m\right), r, w, R\right]+\eta^{*}\left[t_{l}, t_{c}, \kappa, \kappa\left(t_{l}-m\right), r, w, R\right]
\end{aligned}
$$

In this study we will measure $L I^{*}, C I^{*}$ and its sum $T I^{*} . L I^{*}$ and $C I^{*}$ will entail both real responses, i.e. substitution among the arguments in the utility functions and non-real responses, in this case income shifting. Generally, the key parameters can be expected to have an effect on both components of the taxable income functions.

\section{B. Empirical Method}

At a general level, when estimating (3) and (4) we will depart from the following linear equation

$$
I_{s}=\alpha_{0} s+\boldsymbol{\tau}_{s}^{\prime} \boldsymbol{\alpha}_{\mathbf{1}}+s^{*}\left(\mathbf{x}^{\prime} \boldsymbol{\alpha}_{\mathbf{2}}+\mathbf{q}^{\prime} \boldsymbol{\alpha}_{3}\right)+\left(\mathbf{x}^{\prime} \boldsymbol{\alpha}_{4}+\mathbf{q}^{\prime} \boldsymbol{\alpha}_{5}\right)+\varepsilon_{s}
$$

where the dependent variable $I$ is one of our three income measures, CI, LI or TI . $s$ is a linear time trend, $\boldsymbol{\tau}$ a vector of tax variables, $\mathbf{x}$ a vector of individual specific time-invariant observable characteristics, $\mathbf{q}$ a vector of unobservable traits and $\varepsilon$ the error term. A key feature of (5) is that non-tax factors not only are assumed to have an independent effect on $I$ but they may also interact with the time trend. Differentiating (5) yields

$I_{s+1}-I_{s}=\alpha_{0}+\left(\boldsymbol{\tau}_{s+1}^{\prime}-\boldsymbol{\tau}_{s}^{\prime}\right) \boldsymbol{\alpha}_{\mathbf{1}}+\mathbf{x}^{\prime} \boldsymbol{\alpha}_{\mathbf{2}}+\mathbf{q}^{\prime} \boldsymbol{\alpha}_{3}+\left(\varepsilon_{s+1}-\varepsilon_{s}\right)$

As noted by Blomquist and Selin (2006), insofar as unobservable heterogeneity interacts with the time effect it does not cancel out when differentiating. Thus, as long as $\mathbf{q}$ is correlated with other covariates in (6) an omitted-variables bias might occur if $\mathbf{q}$ is not considered in the estimation. We will address this omitted-variables bias by adding first period income, $I_{s}$, to the set of regressors in (6). Since $I_{s}$ is partly determined by $\mathbf{q}$ in (5) it may serve as a proxy variable for $\mathbf{q}{ }^{15}$ It has been recognised in previous studies (e.g. Gruber and Saez (2002), Kopczuk (2005) and Moffitt and

\footnotetext{
${ }^{15}$ A complicating fact is, of course, that $I_{s}$ is also determined by $\varepsilon_{s}$ in (5) such that $I_{s}$ as a regressor might be correlated with $\left(\varepsilon_{s+1}-\varepsilon_{s}\right)$ in (6). Unfortunately, this is difficult to avoid with data from only two years; see Blomquist and Selin (2006) for an approach for multiple year-differences. One should note, however, that we share this problem with previous work in this literature that for other reasons control for first-period income (e.g. Gruber and Saez (2002), Kopczuk (2005) and Moffitt and Wilhelm (2000).
} 
Wilhelm (2000)), that there is typically a strong mean-reversion effect present in the data; those with very low incomes tend to have considerably higher incomes in the second period and vice versa. A standard procedure has therefore been to control for first-period income - and the results are generally very sensitive for this. Therefore, in practice, our approach to a large extent coincides with previous papers even though our motivation is somewhat more general.

As is well known, it is a requirement for validity in the standard linear regression model that the regressors are orthogonal to the error term. This assumption is surely violated here, since the tax variables $\left(\boldsymbol{\tau}^{\prime}{ }_{s+1}-\boldsymbol{\tau}_{s}{ }_{s}\right)$ are direct functions of the dependent income variable. Following Auten and Carroll (1999) and many subsequent taxable income papers, we will construct instruments by calculating marginal tax rates and tax payments using information about period $s$. The idea is that the difference between the "synthetic" net-of-tax rate and tax bill in period $s+1$ and the actual net-oftax rate and tax bill in period $s$ should only reflect pure exogenous tax law changes. We will use this synthetic difference as an instrument in common two-stage-least-squares, 2SLS, regressions.

However, as emphasised by Moffitt and Wilhelm (2000), there is still a possibility that transitory changes in income might invalidate our instruments, which are functions of first period income $I_{s}$ and accordingly also of $\varepsilon_{s}$. Thus there might be a correlation between the instrument and $\varepsilon_{s+1}-\varepsilon_{s}$. In the empirical application, we have attempted to mitigate this source of bias by restricting our sample to those individuals who did not receive unemployment benefits in 1992 or in 1995 . The presumption is that these individuals are less likely to be exposed to transitory shocks in income one of the years.

\section{Empirical Model}

In the empirical model, $\kappa$ in the theoretical model above is represented by a dummy variable, $S E L F$, for self employment status based on its pre-reform value. The marginal cost of income shifting is represented by the two interaction terms $\operatorname{SELF} *(1-t)_{l}$ and $\operatorname{SELF} *(1-t)_{c}$. The change in the total tax payments, where the imputation credit paid by the firm is also included, is added to the independent variables in order to provide a rough measure of the virtual income term $R \cdot{ }^{16}$ The

\footnotetext{
${ }^{16}$ The standard approach in the literature (see, for example, Gruber and Saez (2002) and Kopczuk (2005)) is to capture the income effect by the change in disposable income before and after the reform. However, with only one difference it is very difficult to identify changes in disposable income from other covariates that are closely correlated to the change in disposable income. On the other hand, it has been possible to isolate the effects from total tax payments , which are very closely correlated to changes in disposable income.
} 
linear time effect $s$ in (5) captures the effect from the interest rate, $r$ in (3) and (4), since $r$ does not vary cross-sectionally. We let unobserved exogenous characteristics associated with the wage rate, $w$, be captured by our first period income control. Dummy variables for gender, marital status, secondary school, academic degree, having at least one child and living in the Helsinki area are added to the regressions in order to control for observable characteristics determining $w$. Further, continuous variables for age and squared age are included. Moreover, we allow the first period income control to interact with SELF , as Finland recovered from a deep recession during the period of study. One can then expect employees and the self-employed to react differently to dramatic changes in the macro-economic environment. Finally, we adhere to the well-established convention to use log-log specifications and net-of-tax rates, $(1-t)_{c}$ and $(1-t)_{l}$ rather than marginal tax rates as regressors. Then (6) becomes

$$
\begin{aligned}
\Delta \log I_{s+1} & =\beta_{0}+\beta_{1 i} \sum_{i=c, l} \Delta \log (1-t)_{i s+1}+\beta_{2 i} \sum_{i=c, l} S E L F^{*} \Delta \log (1-t)_{i s+1}+ \\
& +\beta_{3} \Delta \log T A X+\beta_{4} \text { controls }+\beta_{5} \log I_{s}+\beta_{6} S E L F^{*} \log I_{s}+\left(\varepsilon_{s+1}-\varepsilon_{s}\right)
\end{aligned}
$$

These are the key equations to be estimated in this paper. ${ }^{17}$ Estimating (7) is rather straightforward for $L I$ and $T I$. With respect to $C I$, however, two immediate problems must be considered. First, a large number of taxpayers have zero or negative capital income (interest payments exceed positive capital income). Hence, the laws of mathematics prohibit us from using these observations when estimating (7) in logarithmic form. Second, as explained above in Section 2, almost all variation in the labour net-of-tax rate, $(1-t)_{l}$, is a function of the amount of capital income, $C I$, in 1992. As the instrument to such a large degree is a function of CI in 1992 it is surely correlated with the error term and therefore not valid. Thus, our main equation for $C I$ is an equation in non-logarithmic form where $(1-t)_{l}$ is dropped:

$$
\begin{aligned}
\Delta C I_{s+1}= & \gamma_{0}+\gamma_{1} \Delta(1-t)_{c, s+1}+\gamma_{2} \operatorname{SELF} * \Delta(1-t)_{c, s+1}+\gamma_{3} \Delta T A X \\
& +\gamma_{4} \text { controls }+\gamma_{5} C I_{s}+\gamma_{6} S E L F * C I_{s}+\left(e_{s+1}-e_{s}\right)
\end{aligned}
$$

\footnotetext{
${ }^{17}$ Since the optimal amounts of $C I, L I$ and $T I$ are chosen simultaneously we have a system of simultaneous equations with correlated error terms. However, since this system of equations will be just identified, i.e. the number of instruments will equal the number of endogenous regressors, this cannot be utilised for efficiency gains. Three-stageleast-squares, 3SLS, simply collapses to equation-by-equation 2SLS under these circumstances. Or more generally, the multiple-equation generalised method of moments (GMM), of which 3SLS is a special case, boils down to equation-byequation IV-estimation if all equations are just identified (see Hayashi (2000), p. 273).
} 
In addition to the key models (7) and (8) we also estimate a number of alternative specifications in order to test the robustness of the results.

\section{Description of data}

Our data set is based on all individuals in the Income Distribution Survey (IDS) of Statistics Finland, 1992. The IDS is a representative sample of Finnish households, based on both interview and register data. Most of the income data and all tax data are based on registers. We create a panel of these individuals by gathering their register-based tax data from 1995. Since, as stated above, we do not want transition out from and into unemployment to blur our analysis, we exclude individuals who received unemployment benefits in 1992 or in 1995. By similar reasoning, we also leave retired individuals out, i.e. we exclude those over 62 years of age in 1992. As a consequence, our final sample contains 10,007 taxpayers.

The main difficulty in data construction is to make sure that the tax base is as constant as possible. With a non-constant tax base, effects coming from changes in the tax rate and changes in the tax base would be mixed. The task is demanding in the present context, as both the legislation covering the division of income into labour and capital income and statistical classification changed. The following issues arise. First, we exclude forest income (since there was a major change in forest taxation with the old system still in parallel use) and capital gains. Capital gains are especially

problematic, since taxpayers did not need to report all of them prior to the tax reform. Furthermore, legislation governing the presumed acquisition costs was changed. Omitting capital gains is also justified within a short-run analysis, as the timing of their realisation is particularly sensitive to the tax reform. By symmetry, we also exclude realised losses. Second, we exclude imputed income from owner-occupied housing from the 1992 income, since it was not included any more after the reform.

Third, for owners of profitable corporations all dividends were treated as capital income in 1992, while they were divided into labour and capital income from 1993 on, also on the basis of net worth. We have corrected for this by simply adding dividends taxed as labour income back to the capital income tax base in 1995. Fourth, and what is most problematic for our analysis, is the change in the legislation concerning division of business income between earned income and capital income (as described in Section 2 and Appendix A). In 1992, all business income for sole proprietors was seen as earned income up to a certain monetary limit (which depended on the family 
type). From 1993, the division was based on the net worth of the firm. Income equal to 15 percent of the net worth of the enterprise was regarded as business income and the rest was taxed as earned income.

Tracing income shifting among sole proprietors and partnership owners would be straightforward if the data contained information on the net worth of the firms before and after the tax reform. Unfortunately, this information is only available after the reform. In order to create as constant a tax base as possible we have therefore subtracted the imputed share of the net worth from the capital income tax base in 1995 (and added this amount back to the labour income tax base). Accordingly, we do not observe movements in the net worth. Therefore, our estimates provide something of a lower bound to income shifting.

When the tax bases are calculated with these modifications, we obtain our three main concepts of labour income: $L I$, capital income, $C I$, and total income $T I . L I$ is simply labour income subject to $\operatorname{tax}^{18}$, net capital income, $C I$, is defined by gross capital income subject to tax (dividends, rental income etc.) minus interest payments. Finally, $T I$ is the aggregate of $L I$ and $C I$. Information about the mean overall changes between 1992 and 1995 for employees and the self-employed in $L I$ and $C I$ across deciles formed on the basis of total income in 1992 are reported in Figures 2 and 3. Figure 2 reveals that capital income increased at the top of the income distribution both for employees and self-employed, but that the increase was more pronounced for the self-employed. Conversely, according to Figure 3 labour income decreased substantially for the self-employed in the highest deciles, especially in the $10^{\text {th }}$ decile. In this decile, there was actually a slight decrease for employees as well.

The marginal tax rates are calculated using a new Finnish microsimulation model JUTTA, developed by Åbo Akademi University and The Labour Institute for Economic Research. For capital income, for instance, the marginal tax rate is calculated by increasing all capital income by 1 per cent, keeping the shares of different forms of capital income constant. The tax rate for labour income is calculated in the same manner. Two special cases deserve to be mentioned. First, a large number of individuals lack positive capital income but claim deductions for interest payments. For these, the capital marginal tax rate is calculated by decreasing mortgage interest payments by one

\footnotetext{
${ }^{18}$ Due to data limitations it was not possible to add deductions for the acquisition of labour income to $L I$.
} 
per cent. Second, many individuals neither have positive nor negative capital income. Their capital marginal tax rate is set equal to the rate at which they can claim interest deductions, which was the most common form of capital income in both years. ${ }^{19}$ We will return to the consequences of this methodology at the end of Section 6.

The tax rates obtained using this procedure are presented in Figures 4 and 5 . There was no clear change in the marginal tax rate for labour income. For capital marginal tax rates, there was a significant reduction for most individuals. The effect was especially pronounced for those in the highest decile. Note that, in both years, we include the tax paid on dividends at the firm level to the individual-level tax rate through the imputation credit. In 1992, the marginal tax rates on capital increased by income, whereas in 1995 the tax schedule was completely flat. However, since the taxpayer could only be credited for the deficit in capital income up to a certain amount (depending on marital status and the number of children, see Section 2) a small number of individuals had zero capital marginal tax rates in 1995. This is also why we instrument for the change in the capital marginal tax rate.

\section{Main results}

In this section we report results from our preferred models. All preferred models include controls for the first period income and the full set of other control variables. The consequences of deviating from the baseline specifications are discussed in Section 6. The results from the basic model on the change in capital income can be viewed in Table 2. In addition to the marginal effects, where the unit of measurement is euro, we also report implied elasticities. We have evaluated the elasticities at the absolute mean values of 1992 for capital income (in bold) and total income (in italics). Information on the main specifications and alternative specifications are provided in Appendix C.

The first column in Table 2 displays the results for the change in capital income, $\Delta C I$. Indeed, there is a very clear response from the change in the capital net-of-tax rate $\Delta(1-t)_{c}$ to the change in capital income. The rather modest marginal effect estimate translates into an elasticity of 2.2

\footnotetext{
${ }^{19}$ In 1992, deductions could not be claimed for interest expenses below 1,500 FIM. However, when computing these capital marginal tax rates we have ignored this threshold. In practice, interest expenses exceed 1,500 FIM, given that the individual decides to borrow money.
} 
when the elasticity is calculated from the small mean level of capital income prior to the reform. The elasticity is much smaller when it is evaluated at the mean level of total income.

When one includes the interaction term between the tax change and entrepreneurial status (the second column in Table 2), one notices that the capital income tax cut only increased taxable capital income for the self-employed. The interaction term is positive and significant whereas the direct effect is insignificant. Given that we control for other differences in personal background, this effect suggests that the difference in reaction is indeed related to self-employment status. The selfemployed can naturally react by increasing their capital income for different reasons, for example because of the increased use of capital in the firms they own. However, it is not clear why this increase is related to specific firms whose owners' tax rates decreased the most. An alternative, and in our opinion a plausible, explanation is that the self-employed had more opportunities to manipulate the tax bases so that part of the more highly taxed labour income tax base is shifted into the more leniently taxed capital income tax base.

In Table 3, the attention is turned to the reaction of change in the log of labour income (the first column) and the change in the log of total income (the second column). In the labour income regression, we include the change in the marginal tax rate on labour income, since this is likely to be among key factors affecting labour income generating processes. As labour income forms the bulk of total income, the labour marginal tax rate is also included in the regression for total income. The results suggest that an increase in the net-of-tax rate on labour income had a positive and significant effect on labour and total income. The elasticities on these, which are of the order of 0.1-0.2, are in line with earlier evidence on the elasticity of taxable income based on Norwegian data reported by Aarbu and Thoresen 2001. As explained earlier, even though there were no cuts in the marginal tax rate directly, some taxpayers saw a variation in the labour marginal tax rate because the tax base on this progressively taxed income became smaller owing to the reform. Another factor which gives some variation to the tax rates are changes in the local tax rate among different local jurisdictions.

Notice that the interaction terms are not significant for these regressions. The cut in the tax rate on capital income had, instead, a positive impact on the total taxable income, but the elasticity is very small. The estimate of our proxy for the income effect has the expected sign: when the overall tax payment ( $\triangle T A X)$ increases, i.e. net-of-tax income goes down, individuals are willing to work more to earn more labour (and total) income. 
Differences between the self-employed and others can also be seen in Table 4, with a different regression on the change in capital income between these two groups. For the self-employed, the cut in the capital marginal tax rate led to an increase in capital income, whereas this was not the case for other taxpayers. The results in Table 5 demonstrate, in contrast, that the reform led to an increase in taxable labour income for employees, but not for the self-employed. When looking at the response of the overall taxable income, one notices that there was a significant but modest positive impact among the employees. However, despite the significant positive effect on capital income, the total income of the self-employed did not increase in a statistically significant way. While the lack of significance can partly be due to the smaller number of observations in the regression for the self-employed, this result can also reflect the tendency to reduce the share of labour income from total income among the self-employed. If the labour income of the self-employed had risen in a similar way to that among other taxpayers, the total income should also have increased. On balance, it seems that income shifting can have played a role behind the response of the self-employed.

\section{Robustness of results}

As mentioned earlier, the tables in Appendix C include the full results of the key specifications discussed above. These are reported in Column 1 of Tables C.1, C.2 and C.3. In the regression on change in capital income (Table C.1), the other cases we consider include the following specifications: no mean reversion controls (Column 2), the change in the tax payment ( $\triangle T A X$ ) excluded (Column 4), and the change in the labour net-of-tax rate included (Column 5). Column 3 includes the full results in the case where interaction terms are not included.

The results from these robustness checks demonstrate that controlling for the base year income (as a control for reversion to the mean) is important, as in the earlier literature on taxable income elasticity. Without it, the results tend to be stronger, but less reliable. In contrast, the exclusion of the change in average tax payment does not change the results concerning the marginal tax variables. If the labour marginal tax rate is included, the interaction term on the capital marginal tax rate loses significance. Given our discussion in Section 3, this was expected because the tax change for labour income was so strongly related to the cut in the marginal tax rate on capital income. It is more plausible, we think, that the reaction of capital income is more closely related to changes in the taxation of capital. 
The robustness controls for the change in the log of labour income and the change in the log of total income include the same specifications as above, plus two additional ones. These include the specification in the non-logarithmic form (Column 7 in Tables C.2 and C.3) and regression where income weights are used (Column 5) along the lines suggested by Gruber and Saez (2002). The use of income weights is especially important for the reaction of the total income, since total income determines the amount of tax revenu that the government can collect. Finally, we also include specifications where the labour income tax rate is excluded (Column 6).

It appears that the labour income tax rate is a relatively robust determinant of the response in labour income and total income. For labour income, in the specification which is not in logarithmic form, it loses significance. On the other hand, the coefficient for the capital net-of-tax rate is negative and significant. The latter result is consistent with income shifting. For the change in total income, in turn, excluding the overall tax burden makes the change in the labour tax rate insignificant (Column 4). When the labour income net-of-tax rate is excluded (Column 6), the capital marginal tax rate becomes significant instead. This implies that the tax reform indeed led to an increase in labour income and total income, but the response can have arisen in principle from both the labour and capital taxation sides.

When income weights are used, the elasticities of labour and capital income with respect to the change in the labour tax rate increase relative to the non-weighted regressions, reported in the previous section. With income weights, the elasticities are closer to recent US estimates (e.g. in Gruber and Saez 2002) than earlier Scandinavian estimates. However, with income weights, the total income did not increase in a statistically significant way with cuts in the capital marginal tax rate.

For completeness, we have also looked at similar robustness checks separately for the selfemployed and other taxpayers. These results are reported in Tables C.4, C.5 and C.6. Overall, they contain no serious reservations about the main results presented in Section 5. As in the case of the whole sample, including controls for the first period income is important, and including the labour income tax rate for the regression on capital income complicates the interpretation. The labour netof-tax rate remains an important determinant of the labour income and overall income of the employees, whereas abolishing the labour marginal tax rate on the regression on total income makes the cut in capital marginal tax rate significant for the self-employed as well. 
Finally, one may worry whether the way in which we imposed the capital income marginal tax rates on those taxpayers who did not have capital income is correct. To obtain a view on this, we also conducted analysis on a reduced sample where the change in the marginal tax rate on capital income is not calculated for the taxpayers who did not have capital income before the reform. ${ }^{20}$ This serves as a robustness check on how sensitive our results are to imposing marginal tax rates on the taxpayers. The sample size reduces then to 1964 observations. Also in this case, the change in capital income increases in a statistically significant way with respect to an increase in the net-of-tax rate on capital income for the self-employed. In other words, the direct effect is not significant, whereas the interaction term is, as in the regression with the whole sample. ${ }^{21}$

Another way in which to examine the implications of calculating the marginal tax rates, instead of assuming that the marginal tax rate is determined by the asset which is the most common form of capital income, is to use an imputation method to obtain the capital marginal tax rates. Therefore, we developed an alternative way of measuring the capital income: we predicted the capital income based on the value of individuals with similar characteristics with respect to age, sex, education, labour income etc. and used the predicted value of capital income for those who were otherwise similar but did not have capital income. It appeared that when capital income marginal tax rates are calculated this way, their 1992 values tend to be somewhat higher. This is understandable, given that in the imputation method some people get higher values of capital income. Therefore, the aggregate drop in the capital income marginal tax rate also increases. In all essential respects, the qualitative regression results stayed the same, but the alternative procedure tends to increase the point estimates and the significance of the results above. ${ }^{22}$

\section{Conclusion}

Using individual level data, this paper examined the taxable income responses to the Finnish dual income tax reform of 1993. The reform implied that labour income continued to be taxed on a progressive scale, whereas capital income was subject to a flat tax rate from 1993 on. For individuals with high capital income, the reform brought a considerable reduction in the marginal tax rate for

\footnotetext{
${ }^{20}$ These results are available from the authors upon request.

${ }^{21}$ We also ran a Heckman-type selection model, where first we modelled the probability of having capital income, and included the lambda from the first stage to the second stage regression for the change in capital income. We did not detect any evidence of selection bias, even though it also turned out to be difficult to identify the selection term for the lack of appropriate exclusion restrictions.

${ }^{22}$ Again, results with the alternative capital marginal tax rates are available from the authors upon request.
} 
capital income. Therefore, the reform could have changed the incentives to save, but it also meant that the incentive to shift labour income into the more leniently taxed capital income increased.

Our results suggest that there was indeed a modest but statistically significant increase in the overall taxable income following the reform. The elasticities we measure are in accordance with earlier work and vary between 0.1 and 0.4 depending on specification. However, there are marked differences between different taxpayers. Among employees, taxable labour income increased due to the reform, whereas taxable capital income did not. This somewhat surprising result is due to variation in the marginal tax rates on labour income, which were reduced indirectly since the tax base for progressive taxation was reduced when capital income was no longer part of that tax base. The overall taxable income of employees also reacted positively to the reform. In contrast, among the self employed, the reform led to an increase in capital income, whereas labour income and total income did not increase in a statistically significant way. We argue in the paper that the selfemployed have more leeway in manipulating the tax base, and thus it is less costly for them to shift labour income into the capital income tax base. One reason for the different reaction between the two groups can arguably be income shifting. Notice also that we could not capture all incomeshifting activities, such as tax-induced changes in the capital structure of enterprises, due to data limitations.

It therefore appears that while the dual income tax reform could have potentially had positive efficiency gains, part of the benefits were offset by increased income-shifting activities. This has important implications for the design of tax policy. Some have argued that the income-shifting concerns are severe enough to warrant a move towards flat taxes or expenditure tax systems. But one must also bear in mind that the Nordic dual tax systems have varied substantially in the details of tax design. Lindhe et al. (2004) point out that the Finnish version of the dual income tax has created particularly strong incentives for income shifting, whereas the new design in the Norwegian tax system (Sørensen 2005a) is better sheltered against harmful tax planning. What this means is that any dual income tax is not necessarily desirable; once again, the devil lies in the design of the details of a tax system. 


\section{References}

Aarbu, K.O. and T.O. Thoresen (2001) 'Income responses to tax changes - evidence from the Norwegian tax reform', National Tax Journal 54, 319-38.

Auten, G. and R. Carroll (1999) 'The effect of income taxes on household income', The Review of Economics and Statistics 81, 681-693.

Blomquist, S. and H. Selin, (2006), 'Hourly wage rate responsiveness to changes in marginal tax rates’, Uppsala University, mimeo.

Boadway, R. (2004) 'The dual income tax system - an overview’, CESifo DICE Report, 3/2004, 38.

Carroll, R. and W. Hrung (2005) 'What does the taxable income elasticity say about dynamic responses to tax changes’, American Economic Review - Papers and Proceedings 95, 426-431.

Feldstein, M. (1995) 'The effect of marginal tax rates on taxable income: A panel study of the 1986 tax reform act', Journal of Political Economy 103, 551-72.

Fjaerli, E. (2004) 'Tax reform and the demand for debt', International Tax and Public Finance 11, 435-468.

Fjaerli, E. and D. Lund (2001) 'The choice between owner's wage and dividends under the dual income tax', Finnish Economic Papers 14, 104-19.

Giertz, S.H. (2006) 'The elasticity of taxable income in the 1990s: A sensitivity analysis', Congressional Budget Office Working Paper No. 2006-03.

Gordon, R. and J. MacKie-Mason (1994) 'Tax distortions to the choice of organisational form', Journal of Public Economics 55, 279-306.

Gordon, R. and J. Slemrod (2000) 'Are “real” responses to taxes simply income shifting between corporate and personal tax bases?' in Does Atlas shrug? The economic consequences of taxing the rich, J. Slemrod (Ed.). Harvard, Russell Sage Foundation.

Gruber, J. and E. Saez (2002) ‘The elasticity of taxable income: Evidence and implications’, Journal of Public Economics 84, 1-32.

Hagen, K.P and P.B. Sørensen (1998) 'Taxation of income from small businesses: taxation principles and tax reforms in the Nordic countries' in Tax Policy in the Nordic Countries, P.B Sørensen (Ed.). Macmillian Press LTD. 
Hansson, Å. (2004) 'Taxpayers' responsiveness to tax rate changes and implications for the cost of taxation', Lund University, mimeo.

Hayashi, F. (2000) Econometrics, Princeton University Press.

Kari, S. (1999) 'Dynamic behaviour of the firm under dual income taxation', Government Institute for Economic Research, VATT Research Reports 51.

Kopczuk, W. (2005) 'Tax bases, tax rates and the elasticity of taxable income', Journal of Public Economics 89, 2093-2119.

Lindhe T., J. Södersten and A. Öberg (2002) 'Economic effects of taxing closed corporations under a dual income tax', Ifo Studien 48, 575-610.

Lindhe T., J. Södersten and A. Öberg (2004) 'Economic effects of taxing different organizational forms under the Nordic dual income tax’, International Tax and Public Finance 11, 469-85.

Ljunge, M. and K. Ragan (2004) 'Who responded to the tax reform of the century?', University of Chicago, mimeo.

Ministry of Finance (2002) 'A sustainable economy: A foundation of welfare', Economic and Economic Policy Surveys 3/2002.

Moffitt, R.A. and M.O. Wilhelm (2000) 'Taxation and the labor supply decisions of the affluent', in Does Atlas shrug? The economic consequences of taxing the rich, J. Slemrod (Ed.). Harvard, Russell Sage Foundation.

Riihelä, M., R. Sullström and M. Tuomala (2005) ‘Trends in top income shares in Finland', Government Institute for Economic Research, Discussion Paper 371.

Saez, E. (2004) 'Reported income and marginal tax rates, 1960-2000: Evidence and policy implications’, NBER working paper 10273.

Sandmo, A. (2005) 'Inequality and redistribution: A need for new perspectives’, Norwegian School of Economics, Discussion Paper No. 4/2005.

Selén, J. (2004) 'Taxable income responses to tax changes: Panel analyses of Swedish reforms', Mimeo, Trade Union Institute for Economic Research.

Sillamaa, M.-A. and M.R. Veall (2001) 'The effect of marginal tax rates on taxable income: A panel study of the 1988 tax flattening in Canada', Journal of Public Economics 80, 341-56.

Slemrod, J. (1994) 'Fixing the the leak in Okun’s bucket: optimal tax progressivity when avoidance can be controlled', Journal of Public Economics 55, 41-51 
Slemrod, J. (1998) 'Methodological issues in measuring and interpreting taxable income elasticities’, National Tax Journal 51, 773-88.

Slemrod, J. (2001) ‘A general model of the behavioural response to taxation’, International Tax and Public Finance 8, 119-28.

Sørensen, P.B. (1998) 'Recent innovations in Nordic tax policy: from the global income tax to the dual income tax’ in Tax Policy in the Nordic Countries, P.B Sørensen (Ed.). Macmillian Press LTD.

Sørensen, P.B. (2005a). 'Neutral taxation of shareholder income', International Tax and Public Finance 12, 777-801.

Sørensen, P.B. (2005b) ‘Dual income taxation: why and how?’, FinanzArchiv 61, 559-586.

Valkonen, T. (1999) 'The Finnish corporate and capital income tax reform’, The Research Institute of the Finnish Economy, ETLA A 29.

Wu, S.-Y. (2005) 'The tax effect of taxable income from privately held businesses', Southern Economic Journal 71, 891-912. 


\section{Appendix A}

\section{Taxation of self-employed individuals}

For sole proprietorships and partnerships, all income was taxed at the personal level in 1995. After the reform, a certain fraction, $15 \%$, of the net worth of the firm, i.e. business assets minus the stock of business debt, was treated as capital income. In 1992, all income not exceeding a certain monetary limit (depending on family type) was treated as labour income and the residual as capital income. After the reform labour income was defined as net profits, i.e. gross profits of the firm minus interest payments of total debts, minus the share of the net worth that is taxed as capital income. Mathematically, the tax payment of the owner of the non-corporate firm, who is supposed to be situated at a linear segment of the tax schedule, can be expressed as (c.f. Hagen and Sørensen (1998, p.60))

$$
\operatorname{Tax}=t_{l}[\Pi-r Z-k(Y-Z)]+t_{c} k(Y-Z)
$$

where $t_{l}$ denotes the labour income tax rate, $t_{c}$ the capital income tax rate, $\Pi$ is gross profits, $Y$ the book value of taxable assets, $Z$ the stock of business debt, $r$ the interest rate and $k$ the fraction of the net worth that is treated as capital income. Apparently, as $t_{l}>t_{c}$, expanding the net worth of the firm increases the share of tax-favoured capital income. Note, however, that the business owner, in general, cannot expand $Y$ without also increasing $\Pi$. Therefore, the individual is most likely to expand the net worth by reducing their debt burden, but then he or she also expands her labour income, $L I=\Pi-r Z$. We have eliminated the net worth from $L I$ in the regressions in order to keep the labour income tax base constant.

Owners of closely held corporations have the choice to extract income either as wage income or as dividends. Furthermore, they also have the option to keep profits inside the corporation, where it is taxed according to the profit tax rate, i.e. 25\%. As outlined in Section 2, after the reform capital income was determined as a fraction, $15 \%$, of the net worth of the corporation - residual dividends were taxed as labour income. The absence of double taxation of dividends amplified the favourable treatment of dividends in relation to wage income. Below, we will analyse the profit tax as a tax on dividends, thus abstracting from the imputation credit system. Retaining the above notation while 
introducing $D$ for total dividends, $W$ for wage income and $\tau$ for the profit tax rate we are able to write the tax bill of the owner of the closely held corporation as

$$
\operatorname{Tax}=t_{l}[D-k(Y-Z)+W]+\tau k(Y-Z)
$$

From (A-2) it is obvious that expansion of the net worth could be an efficient mean to reduce tax payment. To be a proper description of the income-shifting choice of the individual (A-1) and (A-2) should ideally also feature expressions for payroll taxes. However, since payroll taxes are equal to all individuals in our panel we do not consider them here. 


\section{Appendix B.}

Summary statistics

\begin{tabular}{|c|c|c|c|}
\hline$\Delta C I$ & $\begin{array}{c}1042.581 \\
(6486.242)\end{array}$ & AGE2 & $\begin{array}{l}1879.381 \\
(934.068)\end{array}$ \\
\hline$\Delta L I$ & $\begin{array}{c}1095.325 \\
(9382.793)\end{array}$ & EDUCATION & $\begin{array}{c}0.484 \\
(0.500)\end{array}$ \\
\hline$\Delta T I$ & $\begin{array}{c}2137.906 \\
(10284.820)\end{array}$ & ACADEMIC DEGREE & $\begin{array}{c}0.211 \\
(0.408)\end{array}$ \\
\hline$\Delta(1-t)_{c}$ & $\begin{array}{c}0.133 \\
(0.114)\end{array}$ & HAVING CHILDREN & $\begin{array}{c}0.495 \\
(0.500)\end{array}$ \\
\hline$\Delta(1-t)_{c}$ instrument & $\begin{array}{c}0.135 \\
(0.116)\end{array}$ & HELSINKI AREA & $\begin{array}{c}0.189 \\
(0.392)\end{array}$ \\
\hline$\Delta(1-t)_{l}$ & $\begin{array}{l}-0.003 \\
(0.103)\end{array}$ & $\Delta \log L I$ & $\begin{array}{c}0.060 \\
(0.543)\end{array}$ \\
\hline$\Delta(1-t)_{l}$ instrument & $\begin{array}{l}-0.002 \\
(0.044)\end{array}$ & $\Delta \log T I$ & $\begin{array}{c}0.109 \\
(0.515)\end{array}$ \\
\hline$\triangle T A X$ & $\begin{array}{c}833.132 \\
(4997.599)\end{array}$ & $\Delta \log (1-t)_{C}$ & $\begin{array}{c}0.223 \\
(0.291)\end{array}$ \\
\hline$\triangle T A X$ instrument & $\begin{array}{c}244.021 \\
(2259.069)\end{array}$ & $\Delta \log (1-t)_{c}$ instrument & $\begin{array}{c}0.225 \\
(0.292)\end{array}$ \\
\hline$C I_{92}$ & $\begin{array}{c}-800.289 \\
(4515.154)\end{array}$ & $\Delta \log (1-t)_{l}$ & $\begin{array}{l}-0.006 \\
(0.204)\end{array}$ \\
\hline$L I_{92}$ & $\begin{array}{c}20488.330 \\
(13957.210)\end{array}$ & $\Delta \log (1-t)_{l}$ instrument & $\begin{array}{l}-0.005 \\
(0.102)\end{array}$ \\
\hline$T I_{92}$ & $\begin{array}{c}19688.040 \\
(14120.840)\end{array}$ & $\Delta \log T A X$ & $\begin{array}{c}0.128 \\
(0.887)\end{array}$ \\
\hline SELF & $\begin{array}{c}0.133 \\
(0.339)\end{array}$ & $\Delta \log T A X$ instrument & $\begin{array}{c}0.074 \\
(0.336)\end{array}$ \\
\hline$M A L E$ & $\begin{array}{c}0.504 \\
(0.500)\end{array}$ & $\log L I_{92}$ & $\begin{array}{c}9.712 \\
(0.710)\end{array}$ \\
\hline MARRIED & $\begin{array}{c}0.707 \\
(0.455)\end{array}$ & $\log T I_{92}$ & $\begin{array}{c}0.189 \\
(0.392)\end{array}$ \\
\hline$A G E$ & $\begin{array}{c}41.890 \\
(11.163)\end{array}$ & & \\
\hline Number of observations & 10007 & & 10007 \\
\hline
\end{tabular}




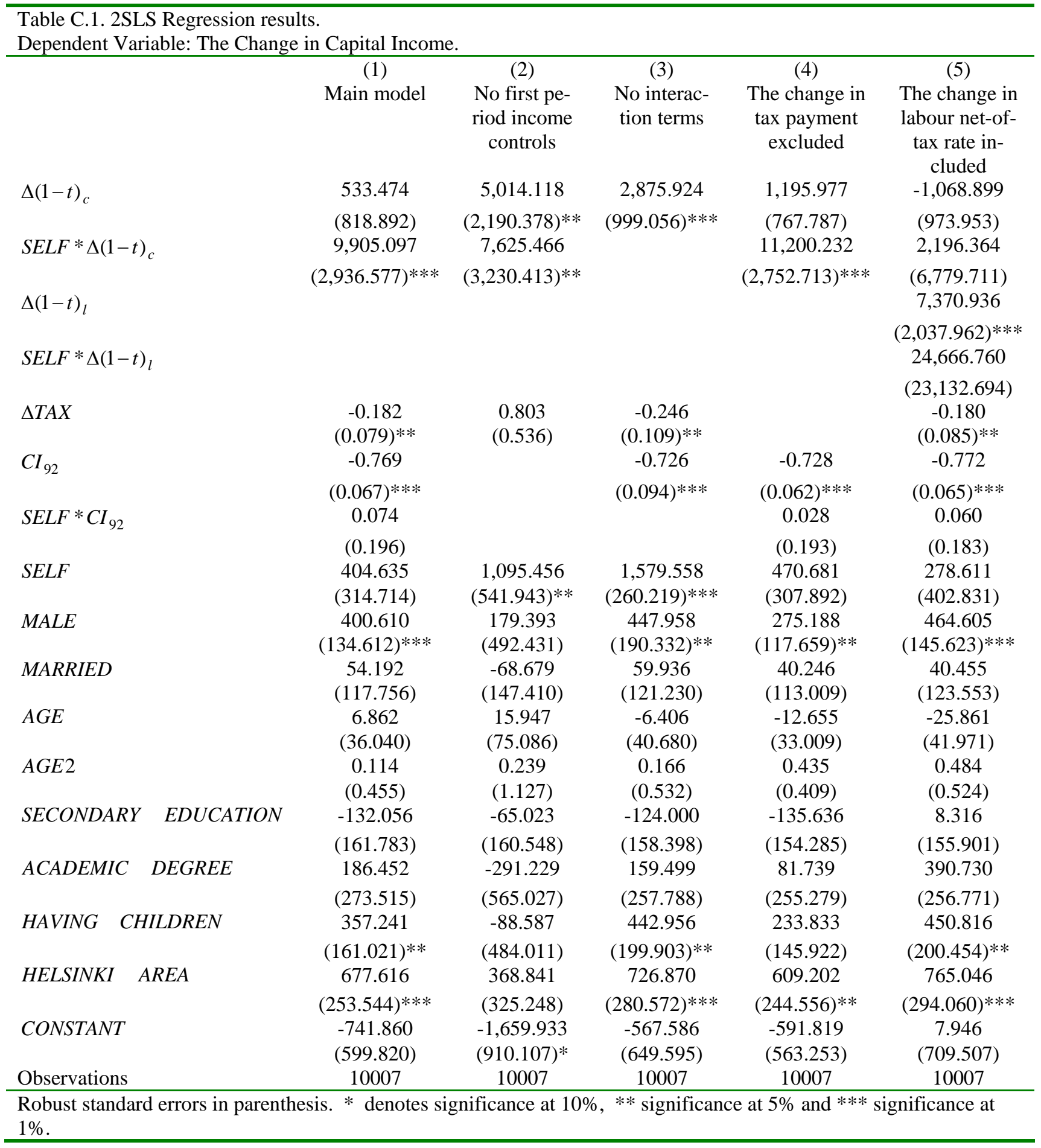




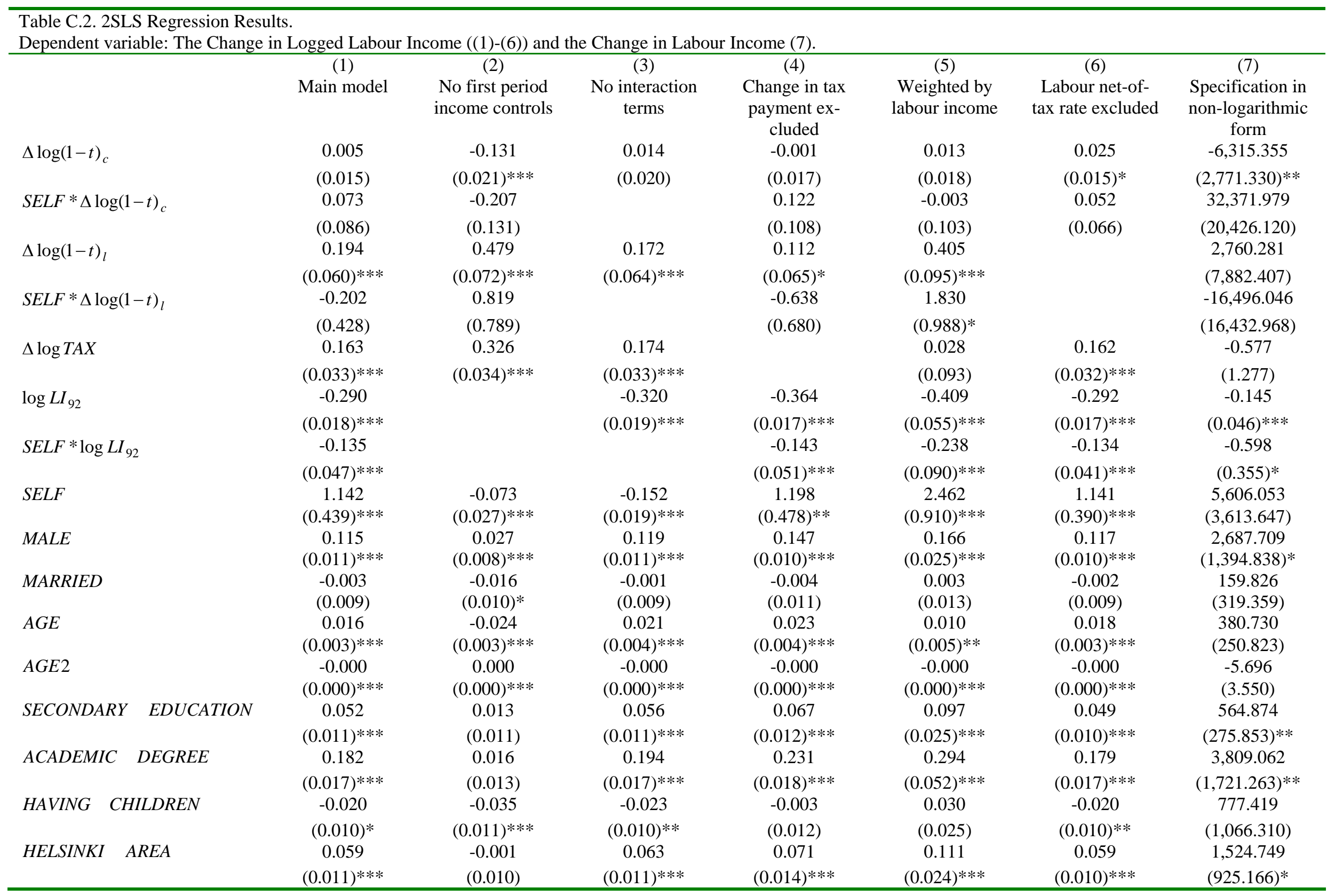




\begin{tabular}{|c|c|c|c|c|c|c|c|}
\hline Observations & $\begin{array}{c}2.507 \\
(0.143)^{* * *} \\
10007\end{array}$ & $\begin{array}{c}0.599 \\
(0.062)^{* * *} \\
10007\end{array}$ & $\begin{array}{c}2.686 \\
(0.150)^{* * *} \\
10007\end{array}$ & $\begin{array}{c}3.089 \\
(0.134)^{* * *} \\
10007\end{array}$ & $\begin{array}{c}3.843 \\
(0.512)^{* * *} \\
10007\end{array}$ & $\begin{array}{c}2.486 \\
(0.140)^{* * *} \\
10007\end{array}$ & $\begin{array}{c}-2,689.843 \\
(3,502.666) \\
10007\end{array}$ \\
\hline
\end{tabular}




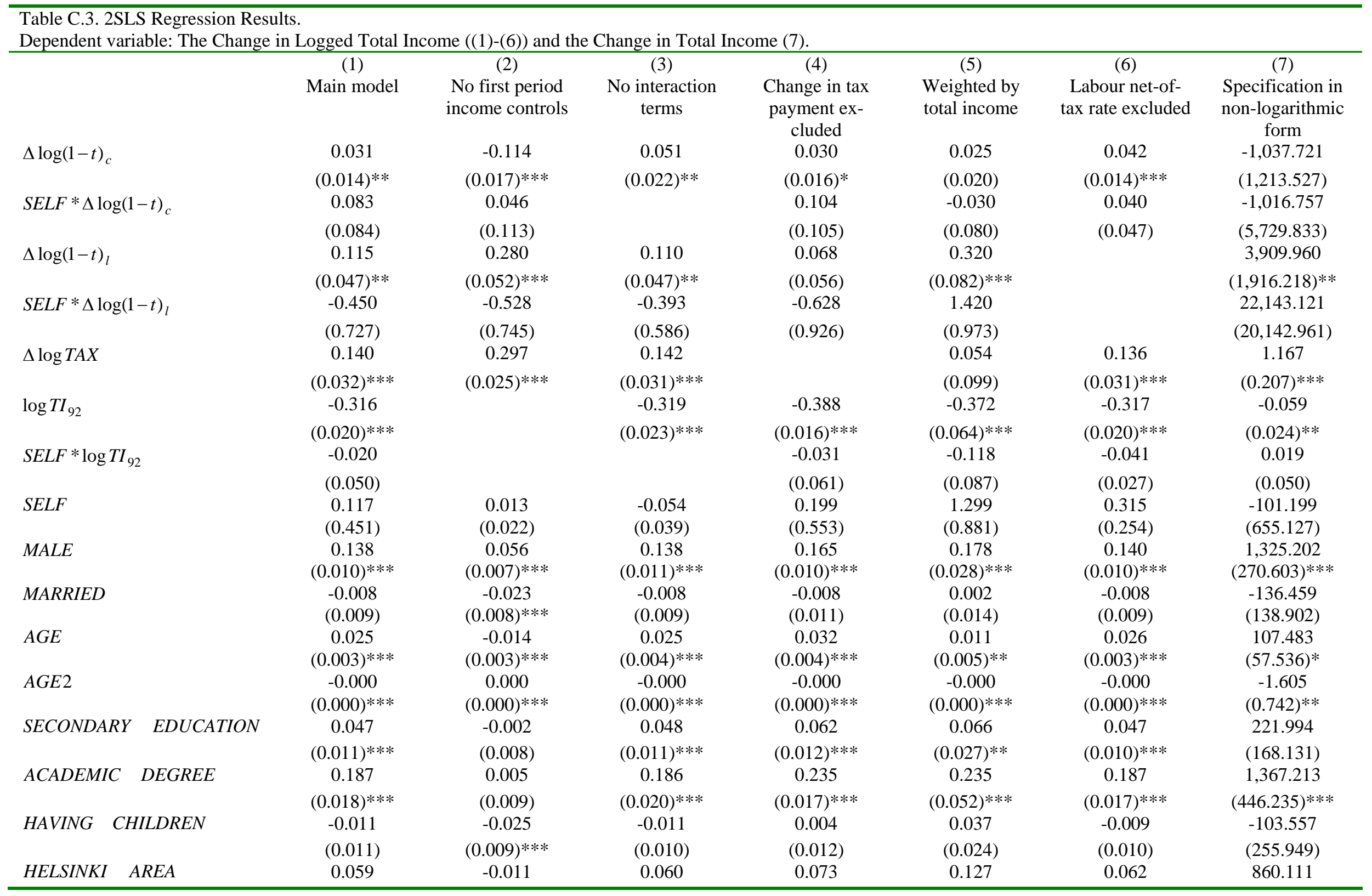




\begin{tabular}{|c|c|c|c|c|c|c|c|}
\hline & $(0.013)^{* * *}$ & $(0.009)$ & $(0.012) * * *$ & $(0.015)^{* * *}$ & $(0.029)^{* * *}$ & $(0.011)^{* * *}$ & $(300.379)^{* * *}$ \\
\hline \multirow{2}{*}{ CONSTANT } & 2.587 & 0.454 & 2.611 & 3.161 & 3.485 & 2.585 & -200.176 \\
\hline & $(0.166)^{* * *}$ & $(0.054)^{* * *}$ & $(0.180)^{* * *}$ & $(0.128)^{* * *}$ & $(0.592)^{* * *}$ & $(0.158)^{* * *}$ & (910.270) \\
\hline Observations & 10007 & 10007 & 10007 & 10007 & 10007 & 10007 & 10007 \\
\hline
\end{tabular}


Table C.4. Separate 2SLS Regressions Results for Employees and Self-Employed.

Dependent Variable: The Change in Capital Income.

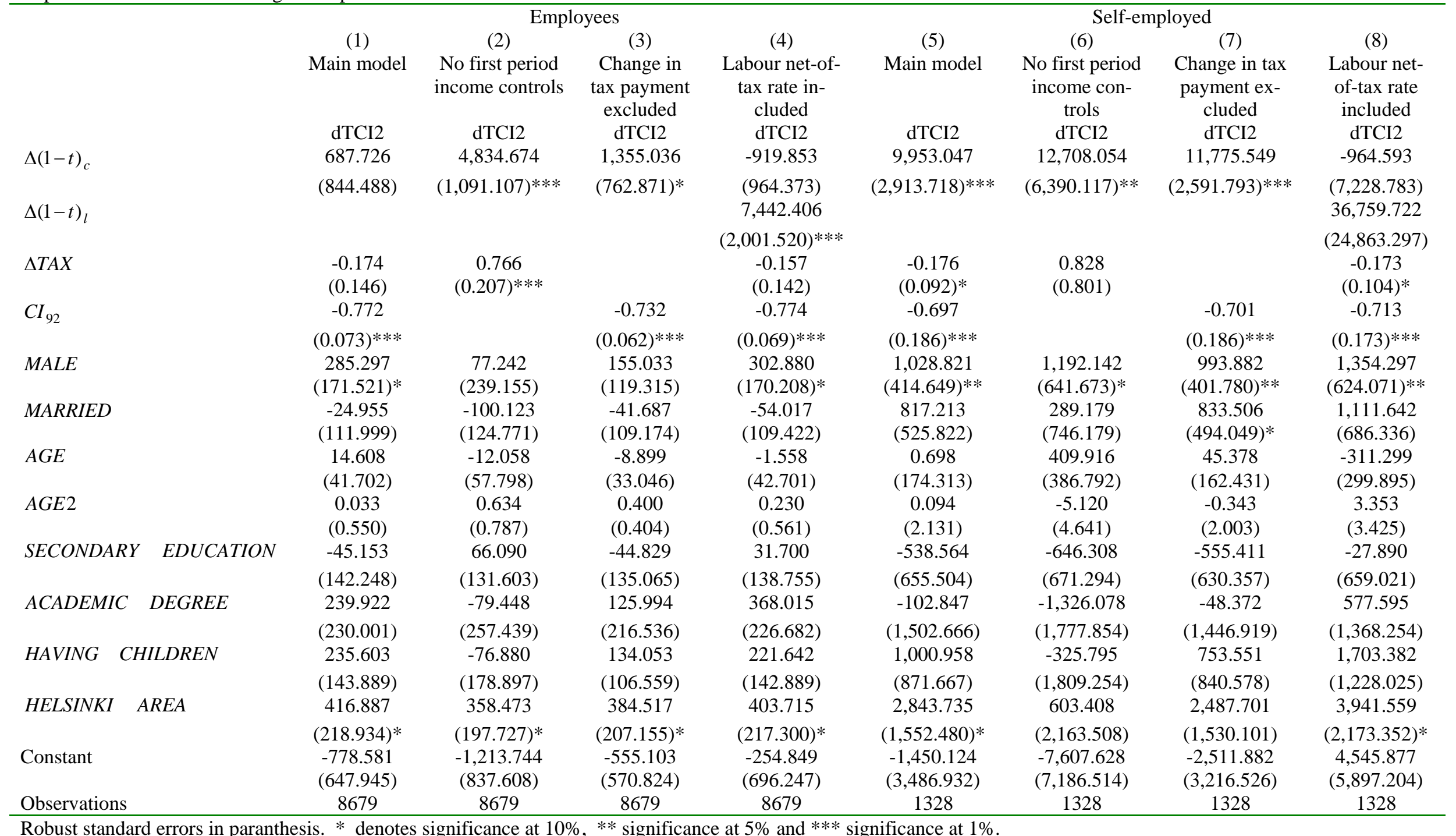


Table C.5. Separate 2SLS Regressions Results for Employees and Self-Employed.

Dependent Variable: The Change in Logged Labour Income ((1)-(5), (7)-(11)) and the Change in Labour Income ((6), (12)).

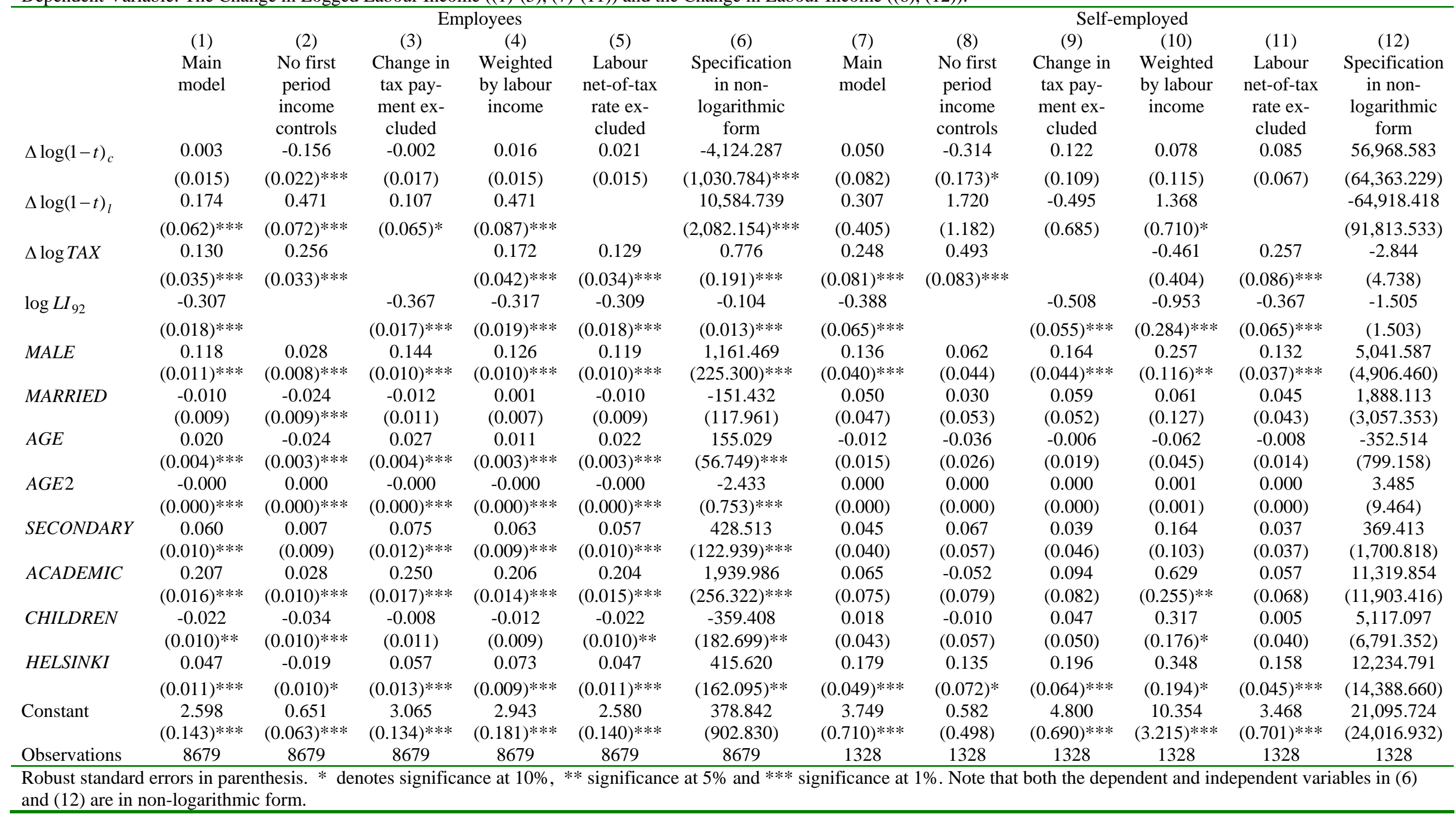




\begin{tabular}{|c|c|c|c|c|c|c|c|c|c|c|c|c|}
\hline \multicolumn{12}{|c|}{$\begin{array}{l}\text { Table C.6. Separate 2SLS Regressions Results for Employees and Self-Employed. } \\
\text { Dependent Variable: The Change in Logged Labour Income ((1)-(5), (7)-(11)) and the Change in Labour Income ((6), (12)). }\end{array}$} & Self-employed \\
\hline & (1) & (2) & (3) & (4) & (5) & (6) & (7) & (8) & (9) & (10) & (11) & (12) \\
\hline & $\begin{array}{l}\text { Main } \\
\text { model }\end{array}$ & $\begin{array}{l}\text { No first } \\
\text { period } \\
\text { income } \\
\text { controls }\end{array}$ & $\begin{array}{l}\text { Change in } \\
\text { tax pay- } \\
\text { ment ex- } \\
\text { cluded }\end{array}$ & $\begin{array}{l}\text { Weighted } \\
\text { by labour } \\
\text { income }\end{array}$ & $\begin{array}{l}\text { Labour } \\
\text { net-of-tax } \\
\text { rate ex- } \\
\text { cluded }\end{array}$ & $\begin{array}{l}\text { Specification } \\
\text { in non- } \\
\text { logarithmic } \\
\text { form }\end{array}$ & $\begin{array}{l}\text { Main } \\
\text { model }\end{array}$ & $\begin{array}{l}\text { No first } \\
\text { period } \\
\text { income } \\
\text { controls }\end{array}$ & $\begin{array}{l}\text { Change in } \\
\text { tax pay- } \\
\text { ment ex- } \\
\text { cluded }\end{array}$ & $\begin{array}{l}\text { Weighted } \\
\text { by labour } \\
\text { income }\end{array}$ & $\begin{array}{l}\text { Labour } \\
\text { net-of-tax } \\
\text { rate ex- } \\
\text { cluded }\end{array}$ & $\begin{array}{l}\text { Specification } \\
\text { in non- } \\
\text { logarithmic } \\
\text { form }\end{array}$ \\
\hline$\Delta \log (1-t)_{c}$ & 0.031 & -0.120 & 0.030 & 0.023 & 0.041 & -881.517 & 0.121 & -0.048 & 0.145 & -0.023 & 0.089 & 3,720.136 \\
\hline & $(0.014)^{* *}$ & $(0.018)^{* * *}$ & $(0.016)^{*}$ & $(0.016)$ & $(0.014)^{* * *}$ & $(1,055.155)$ & $(0.084)$ & $(0.114)$ & $(0.111)$ & $(0.201)$ & $(0.047)^{*}$ & $(9,168.910)$ \\
\hline$\Delta \log (1-t)_{l}$ & 0.110 & 0.277 & 0.064 & 0.318 & & $5,310.497$ & -0.332 & -0.210 & -0.578 & 3.091 & & $28,624.216$ \\
\hline & $(0.047)^{* *}$ & $(0.053)^{* * *}$ & $(0.056)$ & $(0.067)^{* * *}$ & & $(1,467.981)^{* * *}$ & $(0.726)$ & $(0.770)$ & (1.005) & (3.515) & & $(30,941.016)$ \\
\hline$\triangle \log T A X$ & 0.134 & 0.279 & & 0.215 & 0.134 & 1.460 & 0.153 & 0.342 & & -1.090 & 0.137 & 0.002 \\
\hline & $(0.034)^{* * *}$ & $(0.027)^{* * *}$ & & $(0.033)^{* * *}$ & $(0.034)^{* * *}$ & $(0.088)^{* * *}$ & $(0.079) *$ & $(0.054)^{* * *}$ & & (1.684) & $(0.074)^{*}$ & (2.116) \\
\hline $\log L I_{92}$ & -0.323 & & -0.394 & -0.273 & -0.322 & -0.042 & -0.322 & & -0.413 & -1.368 & -0.355 & -0.335 \\
\hline & $(0.021)^{* * *}$ & & $(0.016)^{* * *}$ & $(0.027)^{* * *}$ & $(0.021)^{* * *}$ & $(0.019)^{* *}$ & $(0.089)^{* * *}$ & & $(0.071)^{* * *}$ & (1.346) & $(0.057)^{* * *}$ & $(0.448)$ \\
\hline$M A L E$ & $\begin{array}{c}0.140 \\
(0.010)^{* * *}\end{array}$ & $\begin{array}{c}0.055 \\
(0.007)^{* * *}\end{array}$ & $\begin{array}{c}0.167 \\
(0.010)^{* * *}\end{array}$ & $\begin{array}{c}0.137 \\
(0.011)^{* * *}\end{array}$ & $\begin{array}{c}0.140 \\
(0.010)^{* * *}\end{array}$ & $\begin{array}{c}895.657 \\
(121.944)^{* * *}\end{array}$ & $\begin{array}{c}0.131 \\
(0.033)^{* * *}\end{array}$ & $\begin{array}{c}0.070 \\
(0.022)^{* * *}\end{array}$ & $\begin{array}{c}0.151 \\
(0.036)^{* * *}\end{array}$ & $\begin{array}{c}0.444 \\
(0.431)\end{array}$ & $\begin{array}{c}0.137 \\
(0.033)^{* * *}\end{array}$ & $\begin{array}{c}2,747.015 \\
(1,990.212)\end{array}$ \\
\hline MARRIED & $\begin{array}{c}-0.018 \\
(0.009)^{* *}\end{array}$ & $\begin{array}{c}-0.031 \\
(0.008)^{* * *}\end{array}$ & $\begin{array}{l}-0.019 \\
(0.011)^{*}\end{array}$ & $\begin{array}{c}-0.004 \\
(0.009)\end{array}$ & $\begin{array}{c}-0.017 \\
(0.009)^{* *}\end{array}$ & $\begin{array}{c}-284.099 \\
(104.058)^{* * *}\end{array}$ & $\begin{array}{c}0.056 \\
(0.039)\end{array}$ & $\begin{array}{c}0.022 \\
(0.030)\end{array}$ & $\begin{array}{c}0.067 \\
(0.045)\end{array}$ & $\begin{array}{c}0.155 \\
(0.270)\end{array}$ & $\begin{array}{c}0.063 \\
(0.042)\end{array}$ & $\begin{array}{c}1,420.106 \\
(1,774.665)\end{array}$ \\
\hline$A G E$ & $\begin{array}{c}0.028 \\
(0.004)^{* * *}\end{array}$ & $\begin{array}{c}-0.015 \\
(0.003)^{* * *}\end{array}$ & $\begin{array}{c}0.035 \\
(0.004)^{* * *}\end{array}$ & $\begin{array}{c}0.013 \\
(0.004)^{* * *}\end{array}$ & $\begin{array}{c}0.029 \\
(0.003)^{* * *}\end{array}$ & $\begin{array}{c}64.775 \\
(41.732)\end{array}$ & $\begin{array}{c}0.000 \\
(0.016)\end{array}$ & $\begin{array}{l}-0.003 \\
(0.016)\end{array}$ & $\begin{array}{c}0.001 \\
(0.020)\end{array}$ & $\begin{array}{l}-0.100 \\
(0.128)\end{array}$ & $\begin{array}{l}-0.005 \\
(0.014)\end{array}$ & $\begin{array}{c}-531.498 \\
(840.555)\end{array}$ \\
\hline AGE2 & $\begin{array}{l}-0.000 \\
(0.000) * * *\end{array}$ & $\begin{array}{l}0.000 \\
(0.000)^{* * *}\end{array}$ & $\begin{array}{l}-0.000 \\
(0.000)^{* * *}\end{array}$ & $\begin{array}{c}-0.000 \\
(0.000)^{* * *}\end{array}$ & $\begin{array}{c}-0.000 \\
(0.000)^{* * *}\end{array}$ & $\begin{array}{c}-0.965 \\
(0.510)^{*}\end{array}$ & $\begin{array}{l}-0.000 \\
(0.000)\end{array}$ & $\begin{array}{c}0.000 \\
(0.000)\end{array}$ & $\begin{array}{l}-0.000 \\
(0.000)\end{array}$ & $\begin{array}{c}0.001 \\
(0.001)\end{array}$ & $\begin{array}{c}0.000 \\
(0.000)\end{array}$ & $\begin{array}{c}5.685 \\
(9.471)\end{array}$ \\
\hline SECONDARY & $\begin{array}{c}0.060 \\
(0.010)^{* * *}\end{array}$ & $\begin{array}{c}0.003 \\
(0.008)\end{array}$ & $\begin{array}{c}0.077 \\
(0.012)^{* * *}\end{array}$ & $\begin{array}{c}0.044 \\
(0.018)^{* *}\end{array}$ & $\begin{array}{c}0.058 \\
(0.010)^{* * *}\end{array}$ & $\begin{array}{c}219.133 \\
(140.850)\end{array}$ & $\begin{array}{l}-0.007 \\
(0.035)\end{array}$ & $\begin{array}{l}-0.014 \\
(0.030)\end{array}$ & $\begin{array}{c}-0.004 \\
(0.043)\end{array}$ & $\begin{array}{c}0.228 \\
(0.325)\end{array}$ & $\begin{array}{c}0.001 \\
(0.032)\end{array}$ & $\begin{array}{c}279.779 \\
(1,167.339)\end{array}$ \\
\hline ACADEMIC & $\begin{array}{c}0.210 \\
(0.017)^{* * *}\end{array}$ & $\begin{array}{c}0.017 \\
(0.009)^{*}\end{array}$ & $\begin{array}{c}0.260 \\
(0.015)^{* * *}\end{array}$ & $\begin{array}{c}0.169 \\
(0.029)^{* * *}\end{array}$ & $\begin{array}{c}0.206 \\
(0.017)^{* * *}\end{array}$ & $\begin{array}{c}966.306 \\
(330.372)^{* * *}\end{array}$ & $\begin{array}{c}0.051 \\
(0.068)\end{array}$ & $\begin{array}{c}-0.071 \\
(0.042)^{*}\end{array}$ & $\begin{array}{c}0.081 \\
(0.077)\end{array}$ & $\begin{array}{c}0.762 \\
(0.841)\end{array}$ & $\begin{array}{c}0.066 \\
(0.064)\end{array}$ & $\begin{array}{c}3,873.535 \\
(4,987.856)\end{array}$ \\
\hline CHILDREN & $\begin{array}{l}-0.011 \\
(0.010)\end{array}$ & $\begin{array}{c}-0.020 \\
(0.008)^{* *}\end{array}$ & $\begin{array}{c}0.002 \\
(0.011)\end{array}$ & $\begin{array}{c}-0.002 \\
(0.011)\end{array}$ & $\begin{array}{c}-0.012 \\
(0.009)\end{array}$ & $\begin{array}{c}-435.299 \\
(106.332)^{* * *}\end{array}$ & $\begin{array}{c}0.006 \\
(0.048)\end{array}$ & $\begin{array}{c}-0.044 \\
(0.034)\end{array}$ & $\begin{array}{c}0.032 \\
(0.053)\end{array}$ & $\begin{array}{c}0.560 \\
(0.629)\end{array}$ & $\begin{array}{c}0.022 \\
(0.038)\end{array}$ & $\begin{array}{c}2,650.417 \\
(4,056.498)\end{array}$ \\
\hline HELSINKI & 0.053 & -0.017 & 0.065 & 0.080 & 0.053 & 454.614 & 0.119 & 0.032 & 0.145 & 0.739 & 0.145 & $6,666.630$ \\
\hline Constant & $\begin{array}{c}(0.011)^{* * *} \\
2.595 \\
(0.163)^{* * *}\end{array}$ & $\begin{array}{c}(0.009)^{* *} \\
0.478 \\
(0.055)^{* * *}\end{array}$ & $\begin{array}{c}(0.013)^{* * *} \\
3.143 \\
(0.126)^{* * *}\end{array}$ & $\begin{array}{c}(0.013)^{* * *} \\
2.501 \\
(0.225)^{* * *}\end{array}$ & $\begin{array}{c}(0.011)^{* * *} \\
2.569 \\
(0.162)^{* * *}\end{array}$ & $\begin{array}{c}(130.833) * * * \\
376.186 \\
(702.182)\end{array}$ & $\begin{array}{c}(0.073) \\
3.040 \\
(1.018)^{* * *}\end{array}$ & $\begin{array}{c}(0.049) \\
0.163 \\
(0.312)\end{array}$ & $\begin{array}{c}(0.083)^{*} \\
3.893 \\
(0.924)^{* * *}\end{array}$ & $\begin{array}{c}(0.780) \\
15.190 \\
(15.134)\end{array}$ & $\begin{array}{c}(0.049)^{* * *} \\
3.440 \\
(0.620)^{* * *}\end{array}$ & $\begin{array}{c}(7,619.021) \\
12,967.304 \\
(18,960.529)\end{array}$ \\
\hline Observations & 8679 & 8679 & 8679 & 8679 & 8679 & 8679 & 1328 & 1328 & 1328 & 1328 & 1328 & 1328 \\
\hline
\end{tabular}


Figures and Tables

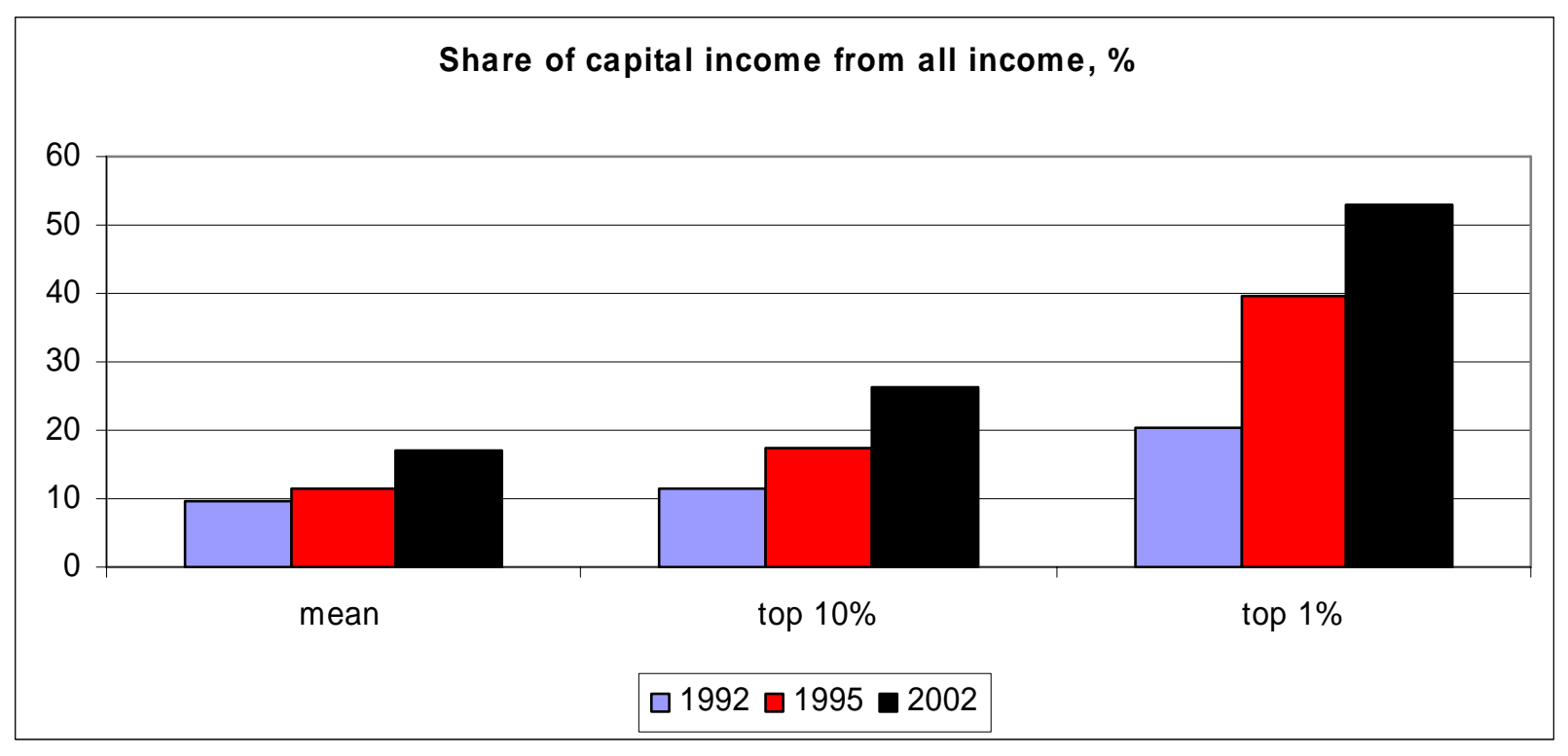

Figure 1: Share of capital income from all factor income in Finland by income groups, 1992-2002. Source: Riihelä et al (2005). 


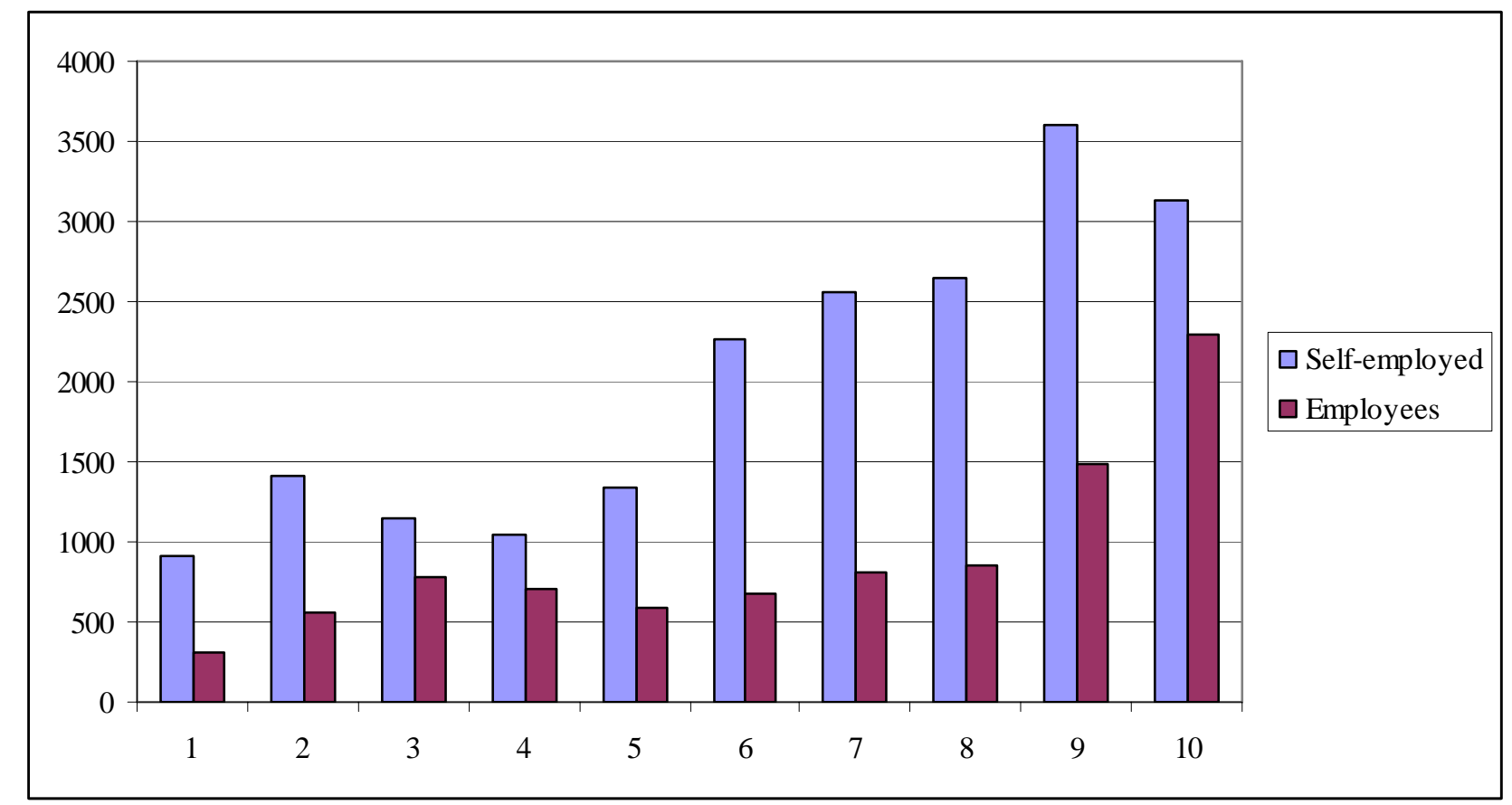

Figure 2. Mean change in capital income (in EUR) from 1992 to 1995 by decile. Deciles are based on total income in 1992.

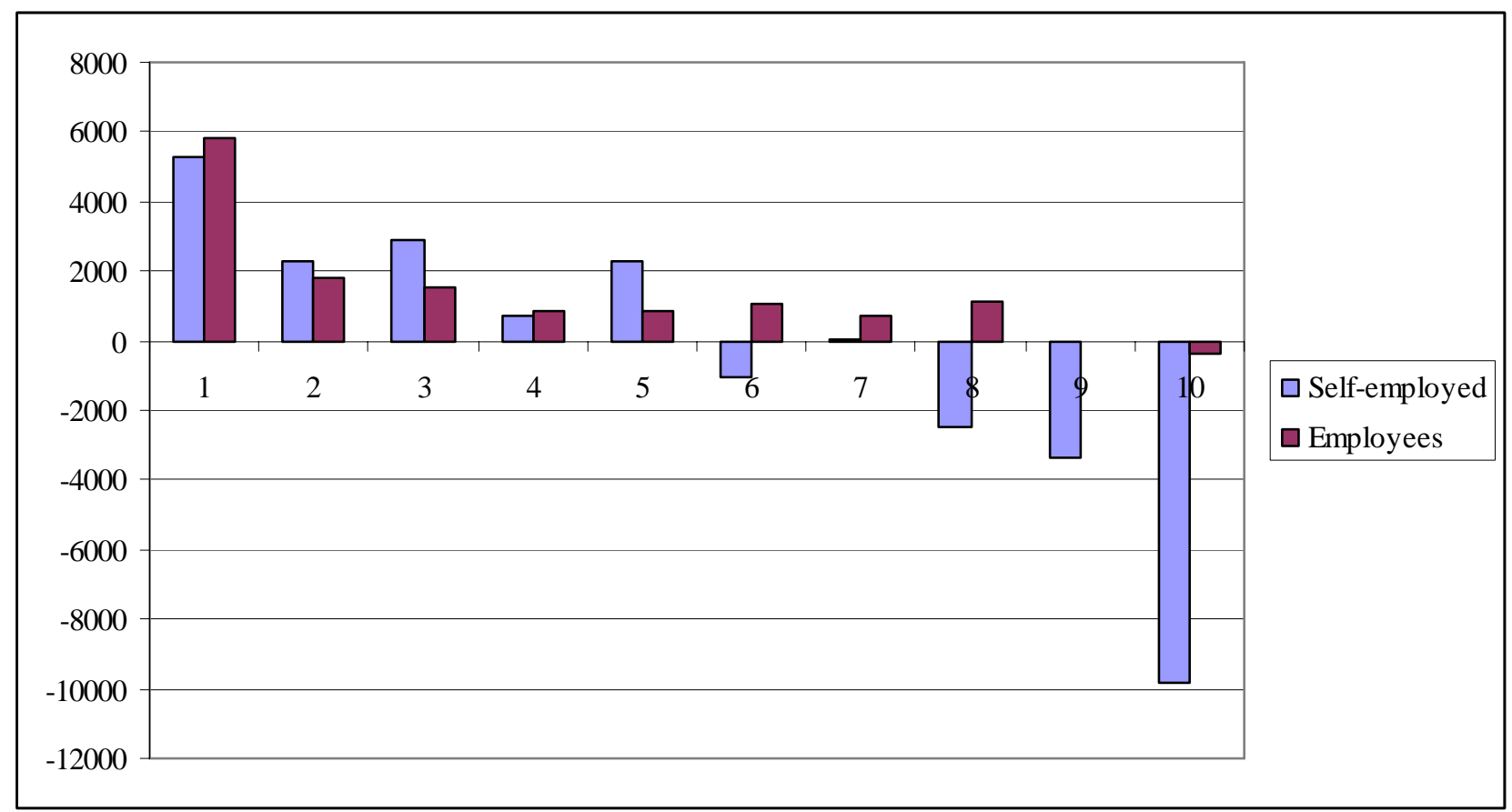

Figure 3. Mean change in labour income (in EUR) from 1992 to 1995 by decile. Deciles are based on total income in 1992. 


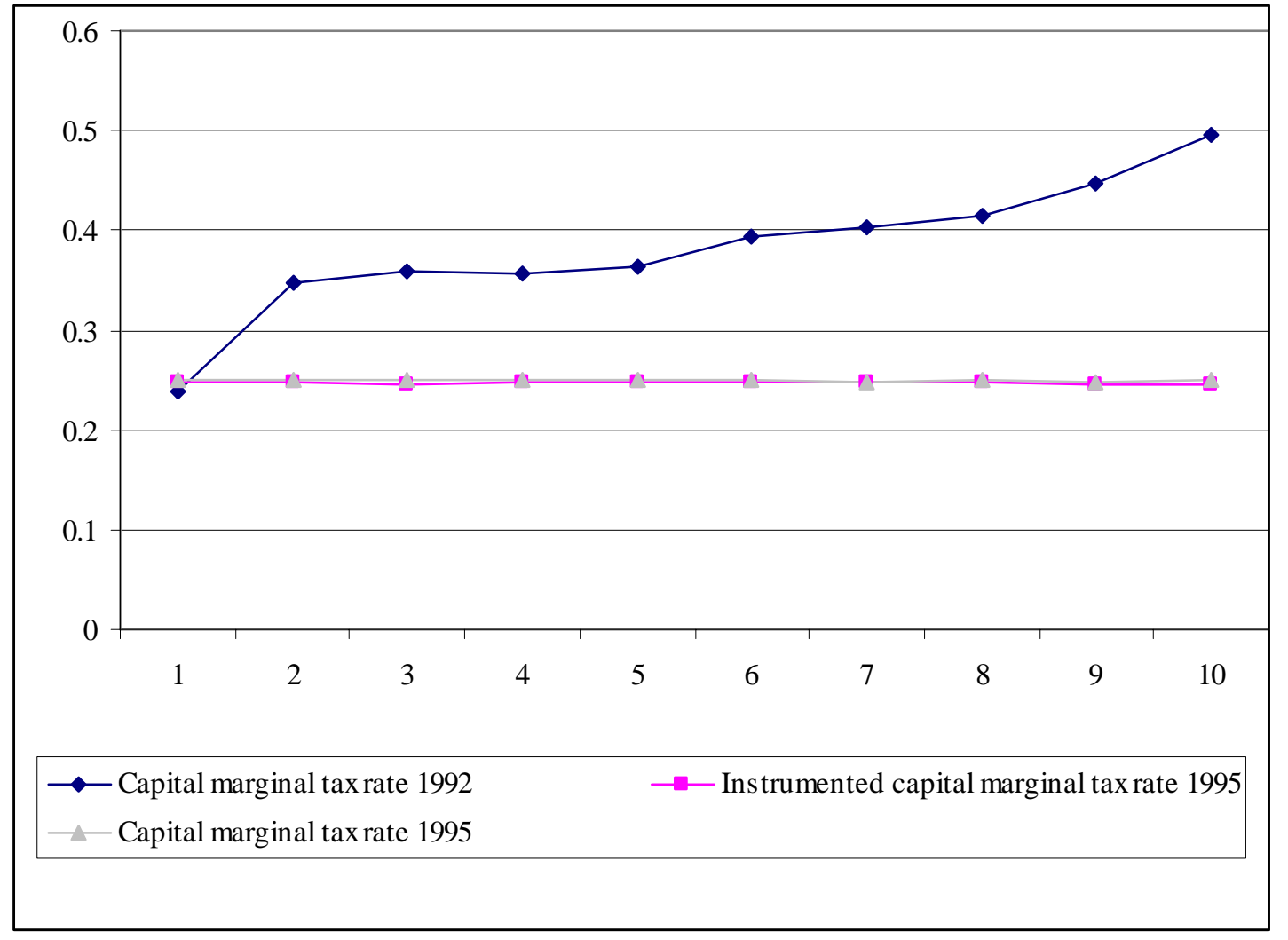

Figure 4. Marginal tax rates on capital income, by deciles based on total income in 1992.

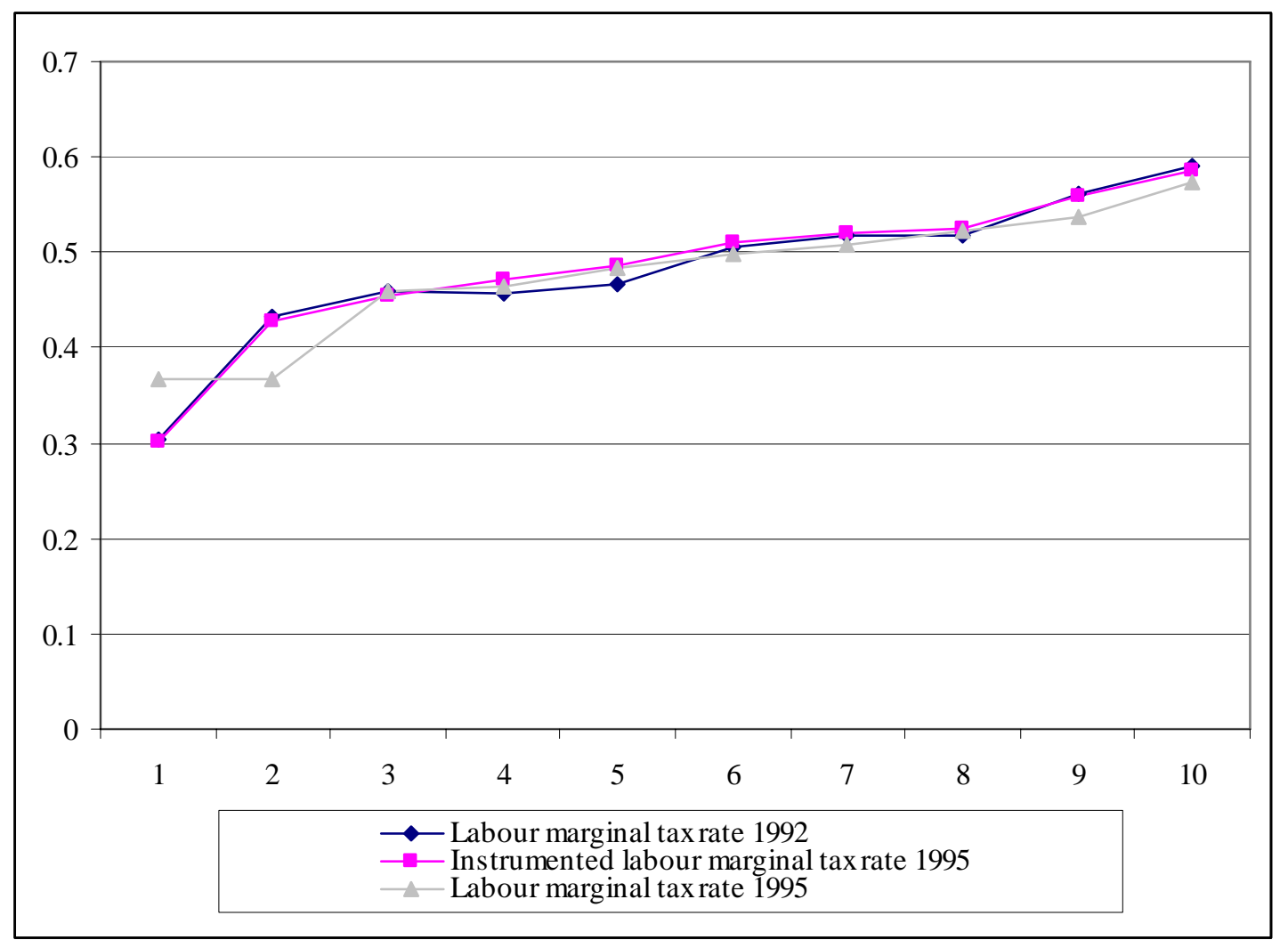

Figure 5. Marginal tax rates on capital income, by deciles based on total income in 1992. 


\begin{tabular}{|l|l|l|}
\hline Taxable income, FIM & $\begin{array}{l}\text { Tax at the lower threshold, } \\
\text { FIM }\end{array}$ & $\begin{array}{l}\text { Marginal tax rate on income } \\
\text { exceeding the lower thresh- } \\
\text { old, \% }\end{array}$ \\
\hline $40,000-56,000$ & 50 & 7 \\
\hline $56,000-70,000$ & 1,170 & 17 \\
\hline $70,000-98,000$ & 3,550 & 21 \\
\hline $98,000-154,000$ & 9,430 & 27 \\
\hline $154,000-275,000$ & 24,550 & 33 \\
\hline $275,000-$ & 64,480 & 39 \\
\hline
\end{tabular}

Table 1: The state income tax schedule in 1992 and 1993. In 1995, the tax rates remained the same, but there was a small inflation adjustment in the threshold levels for income brackets. Source: Ministry of Finance. One euro = 5.9 FIM.

Table 2. 2SLS Regression Results.

Dependent Variable: The Change in Capital Income.

\begin{tabular}{|c|c|c|}
\hline \multirow{5}{*}{$\Delta(1-t)_{c}$} & Reduced model & Main model \\
\hline & 2,881.902 & 533.474 \\
\hline & $(993.645)^{* * *}$ & (818.892) \\
\hline & 2.224 & 0.412 \\
\hline & 0.090 & 0.017 \\
\hline \multirow{4}{*}{$S E L F * \Delta(1-t)_{c}$} & & $9,905.097$ \\
\hline & & $(2,936.577)^{* * *}$ \\
\hline & & 1.021 \\
\hline & & 0.041 \\
\hline \multirow[t]{4}{*}{$\triangle T A X$} & -0.210 & -0.182 \\
\hline & $(0.079) * * *$ & $(0.079) * *$ \\
\hline & -1.887 & -1.635 \\
\hline & -0.077 & -0.066 \\
\hline Number of observations & 10007 & 10007 \\
\hline \multicolumn{3}{|c|}{$\begin{array}{l}\text { Elasticities evaluated at mean absolute capital income in } 1992 \text { in bold face. } \\
\text { Elasticities evaluated at mean total income in } 1992 \text { in italics. All specifications } \\
\text { include first period income controls and other control variables. See Appendix } \\
\text { C for complete results for the main model. Robust standard errors in paranthe- } \\
\text { sis. * denotes significance at } 10 \%, * * \text { significance at } 5 \% \text { and } * * * \text { significance } \\
\text { at } 1 \% \text {. }\end{array}$} \\
\hline
\end{tabular}


Table 3. 2SLS Regression Results.

Dependent Variables: The Change in Logged Labour Income and the Change in Logged Total Income.

\begin{tabular}{lcc}
\hline & $\Delta \log L I$ & $\Delta \log T I$ \\
$\log (1-t)_{c}$ & 0.005 & 0.031 \\
$S E L F * \Delta \log (1-t)_{c}$ & $(0.015)$ & $(0.014)^{* *}$ \\
& 0.073 & 0.083 \\
$\Delta \log (1-t)_{l}$ & $(0.086)$ & $(0.084)$ \\
& 0.194 & 0.115 \\
$S E L F * \Delta \log (1-t)_{l}$ & $(0.060)^{* * *}$ & $(0.047)^{* *}$ \\
& -0.202 & -0.450 \\
$\Delta \log T A X$ & $(0.428)$ & $(0.727)$ \\
Observations & 0.163 & 0.140 \\
\hline
\end{tabular}

All specifications include first period income controls and other control variables. See Appendix C for complete results. Robust standard errors in parenthesis. $*$ denotes significance at $10 \%, * *$ significance at $5 \%$ and $* * *$ significance at $1 \%$.

Table 4. 2SLS Regression Results.

Dependent Variable: The Change in Capital Income.

\begin{tabular}{lcc}
\hline$\Delta(1-t)_{c}$ & Employees & Self-employed \\
& 687.726 & $9,953.047$ \\
& $(844.488)$ & $(2,913.718)^{* * *}$ \\
& $\mathbf{0 . 0 4 3 8}$ & $\mathbf{2 0 . 3 5 6}$ \\
& 0.022 & 0.304 \\
& & \\
$\Delta T A X$ & -0.174 & -0.176 \\
& $(0.146)$ & $(0.092)^{*}$ \\
& $\mathbf{- 1 . 2 6 5}$ & $\mathbf{- 4 . 7 0 6}$ \\
& -0.063 & -0.070 \\
& 8679 & 1328 \\
Observations & & \\
\hline Elasticities evaluated at mean absolute capital income in 1992 in bold face. \\
Elasticities evaluated at mean total income in 1992 in italics. All specifications \\
include first period income controls and other control variables. See Appendix \\
C for complete results. Robust standard errors in parenthesis. $*$ denotes sig- \\
nificance at 10\%, ** significance at 5\% and *** significance at 1\%. \\
\hline
\end{tabular}




\begin{tabular}{|c|c|c|c|c|}
\hline \multirow{4}{*}{$\Delta \log (1-t)_{c}$} & \multicolumn{2}{|c|}{ Employees } & \multicolumn{2}{|c|}{ Self-employed } \\
\hline & $\Delta \log L I$ & $\Delta \log T I$ & $\Delta \log L I$ & $\Delta \log T I$ \\
\hline & 0.003 & 0.031 & 0.050 & 0.121 \\
\hline & $(0.015)$ & $(0.014)^{* *}$ & $(0.082)$ & $(0.084)$ \\
\hline \multirow[t]{2}{*}{$\Delta \log (1-t)_{l}$} & 0.174 & 0.110 & 0.307 & -0.332 \\
\hline & $(0.062)^{* * *}$ & $(0.047)^{* *}$ & $(0.405)$ & $(0.726)$ \\
\hline \multirow[t]{2}{*}{$\Delta \log T A X$} & 0.130 & 0.134 & 0.248 & 0.153 \\
\hline & $(0.035) * * *$ & $(0.034)^{* * *}$ & $(0.081)^{* * *}$ & $(0.079)^{*}$ \\
\hline Observations & 8679 & 8679 & 1328 & 1328 \\
\hline $\begin{array}{l}\text { All specificati } \\
\text { sults. Robust s } \\
\text { cance at } 1 \% \text {. }\end{array}$ & $\begin{array}{l}\text { st period ince } \\
\text { in parenthes }\end{array}$ & $\begin{array}{l}\text { s and other } \\
\text { es significan }\end{array}$ & $\begin{array}{l}\text { bles. See Ap } \\
\text { ** significar }\end{array}$ & $\begin{array}{l}\text { complete } \\
* * * \text { signi }\end{array}$ \\
\hline
\end{tabular}


WORKING PAPERS*

Editor: Nils Gottfries

2005:19 Lennart Berg and Tommy Berger, The Q Theory and the Swedish Housing Market - An Empirical Test. 16 pp.

2005:20 Matz Dahlberg and Magnus Gustavsson, Inequality and Crime: Separating the Effects of Permanent and Transitory Income. 27 pp.

2005:21 Jenny Nykvist, Entrepreneurship and Liquidity Constraints: Evidence from Sweden. 29 pp.

2005:22 Per Engström, Bertil Holmlund and Jenny Nykvist: Worker Absenteeism in Search Equilibrium. 35pp.

2005:23 Peter Hästö and Pär Holmberg, Some inequalities related to the analysis of electricity auctions. 7pp.

2006:1 Jie Chen, The Dynamics of Housing Allowance Claims in Sweden: A discrete-time hazard analysis. 37pp.

2006:2 Fredrik Johansson and Anders Klevmarken: Explaining the size and nature of response in a survey on health status and economic standard. 25pp.

2006:3 Magnus Gustavsson and Henrik Jordahl, Inequality and Trust: Some Inequalities are More Harmful than Others. 29pp.

2006:4 N. Anders Klevmarken, The Distribution of Wealth in Sweden: Trends and Driving factors. 20pp.

2006:5 Erica Lindahl and Andreas Westermark: Soft Budget Constraints as a Risk Sharing Arrangement in an Economic Federation. 22pp.

2006:6 Jonas Björnerstedt and Andreas Westermark: Bargaining and Strategic Discrimination. 36pp.

2006:7 Mikael Carlsson, Stefan Eriksson and Nils Gottfries: Testing Theories of Job Creation: Does Supply Create Its Own Demand? 23pp.

2006:8 Annika Alexius and Erik Post, Cointegration and the stabilizing role of exchange rates. 33pp.

2006:9 David Kjellberg, Measuring Expectations. 46pp.

2006:10 Nikolay Angelov, Modellig firm mergers as a roommate problem. 21pp.

2006:11 Nikolay Angelov, Structural breaks in iron-ore prices: The impact of the 1973 oil crisis. 41pp.

\footnotetext{
* A list of papers in this series from earlier years will be sent on request by the department.
} 
2006:12 Per Engström and Bertil Holmlund, Tax Evasion and Self-Employment in a High-Tax Country: Evidence from Sweden. 16pp.

2006:13 Matias Eklöf and Daniel Hallberg, Estimating retirement behavior with special early retirement offers. 38pp.

2006:14 Daniel Hallberg, Cross-national differences in income poverty among Europe’s 50+. 24pp.

2006:15 Magnus Gustavsson and Pär Österholm, Does Unemployment Hysteresis Equal Employment Hysteresis? 27pp.

2006:16 Jie Chen, Housing Wealth and Aggregate Consumption in Sweden. 52pp.

2006:17 Bertil Holmlund, Quian Liu and Oskar Nordström Skans, Mind the Gap? Estimating the Effects of Postponing Higher Education. 33pp.

2006:18 Oskar Nordström Skans, Per-Anders Edin and Bertil Holmlund, Wage Dispersion Between and Within Plants: Sweden 1985-2000. 57pp.

2006:19 Tobias Lindhe and Jan Södersten, The Equity Trap, the Cost of Capital and the Firm's Growth Path. 20pp.

2006:20 Annika Alexius and Peter Welz, Can a time-varying equilibrium real interest rate explain the excess sensitivity puzzle? 27pp.

2006:21 Erik Post, Foreign exchange market interventions as monetary policy. 34pp.

2006:22 Karin Edmark and Hanna Ågren, Identifying Strategic Interactions in Swedish Local Income Tax Policies. 36pp.

2006:23 Martin Ågren, Does Oil Price Uncertainty Transmit to Stock Markets? 29pp.

2006:24 Martin Ågren, Prospect Theory and Higher Moments. 31pp.

2006:25 Matz Dahlberg, Eva Mörk, Jørn Rattsø and Hanna Ågren, Using a discontinuous grant rule to idenitfy the effect of grants on local taxes and spending. 26pp.

2006:26 Jukka Pirttiläa and Håkan Selin, How Successful is the Dual Income Tax? Evidence from the Finnish Tax Reform of 1993. 40pp.

See also working papers published by the Office of Labour Market Policy Evaluation http://www.ifau.se/

ISSN 1653-6975 